\title{
Seismic hazard and risk scenarios for Barcelona, Spain, using the Risk-UE vulnerability index method
}

\author{
N. Lantada - J. Irizarry - A. H. Barbat - X. Goula • \\ A. Roca - T. Susagna - L. G. Pujades
}

Received: 28 August 2008 / Accepted: 1 August 2009 / Published online: 28 August 2009

(C) Springer Science+Business Media B.V. 2009

\begin{abstract}
The vulnerability index method, in its version developed in the framework of the European project Risk-UE, has been adapted and applied in this article, to evaluate the seismic risk for the city of Barcelona (Spain) through a GIS based tool. According to this method, which defines five damage states, the action is expressed in terms of the macroseismic intensity and the seismic quality of the buildings by means of a vulnerability index. The probabilities of damage states are obtained considering a binomial or beta-equivalent probability distribution. The most relevant seismic risk evaluation results obtained, for current buildings and monuments of Barcelona, are given in the article as scenarios of expected losses.
\end{abstract}

Keywords Seismic hazard - Seismic vulnerability · Risk scenarios · Loss estimation · Urban areas · GIS

\section{Introduction}

Urban physical seismic vulnerability is an internal risk factor which describes the intrinsic predisposition of an urban area to be susceptible to damage when affected by an earthquake. It is basically related to the degree of exposure and the fragility of the elements to cope with the seismic action. Seismic hazard is an external risk factor which can be expressed as the

N. Lantada $(\varangle) \cdot$ L. G. Pujades

Department of Geotechnical Engineering and Geosciences, Civil Engineering School, Technical University of Catalonia, Edificio D2, Campus Norte UPC, Jordi Girona 1-3, 08034 Barcelona, Spain e-mail: nieves.lantada@upc.edu

J. Irizarry $\cdot$ X. Goula $\cdot$ A. Roca $\cdot$ T. Susagna

Institut Geològic de Catalunya, c/Balmes, 209-211, 08006 Barcelona, Spain

A. H. Barbat

Department of Structural Mechanics, Civil Engineering School, Technical University of Catalonia, Edificio C1, Campus Norte UPC, Jordi Girona 1-3, 08034 Barcelona, Spain 
probability of occurrence of an earthquake of certain severity in an urban area during a given period of exposure. It defines the level of severity of the ground motion that can be expected in a region. Urban seismic risk is the convolution of hazard and vulnerability; it describes the potential expected loss which can be represented in maps showing the expected damage of the urban area due to a specified earthquake. Although these definitions make reference only to physical aspects, vulnerability can also include economic, social or political aspects (Carreño et al. 2007a; Barbat et al. 2009). In this case, risk expresses the probability of exceedance of a given level of economic, social or environmental consequences, at a certain site and during a certain period. It has to be mentioned that social aspects of the vulnerability can be the causes of physical dimension of the vulnerability. For management purposes, the objective of risk studies is to improve decisions making, contributing thus to the effectiveness of risk management (Carreño et al. 2007b).

The seismic hazard can be evaluated at both regional and local scales using two principal approaches: one deterministic and the other probabilistic. The deterministic approach is based on the assumption that historical seismicity gives enough information to know the seismic hazard expected in the region, while the probabilistic one analyses the seismicity and the seismotectonic characteristics of a region to obtain its seismic hazard associated to a certain probability of occurrence. Soil effects should be also included in the evaluation of the seismic hazard, that is, the effects of the local geology on the ground motion generated by the seismic event should also be considered. Soft or non-consolidated soils cause amplifications of the ground motion that increment the damages caused by seismic events. In this concern, seismically oriented geological/geotechnical studies are useful, allowing identify-

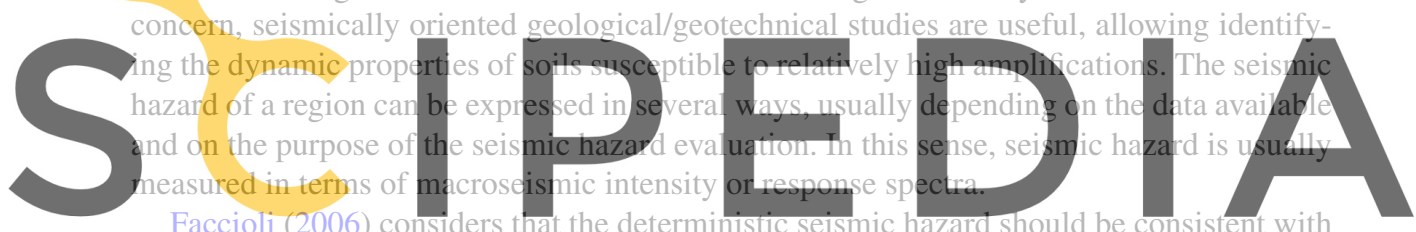

Faccioli (2006) considers that the deterministic seismic hazard should be consistent with

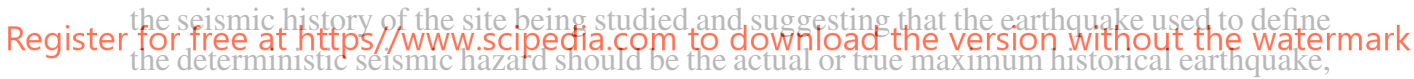

that is, the strongest closest event that had affected the site.

Deterministic seismic hazard maps can be obtained for the studied site by using appropriate intensity and spectral attenuation relationships. In any case, the intensity attenuation relationship must be compatible with the history of the felt intensities in the region.

The probabilistic hazard evaluation approach is based on the probabilistic seismic hazard assessment (PSHA) using the algorithm established by Cornell (1968) with his proposal of a program for the calculation of the seismic hazard that was later enhanced by others such, for instance, McGuire (1976). The definition of the seismic sources can be accomplished through the study of the spatial distribution of the seismicity and the geological, geophysical and seismic characteristics of the influence zone of the site (Grellet et al. 1993; Fleta et al. 1996). A seismic model must be defined for each seismic source describing the temporal occurrence of earthquakes in the zone (Poisson model, Kallberg and Cornell 1969) as well as the frequency of occurrence of earthquakes according to its magnitude (Gutenberg-Richter law, Gutenberg and Richter 1954). Once the seismicity of the sources is characterized, the distribution of the parameter indicating the seismic hazard at the site must be obtained for each zone using an appropriate attenuation relationship. Finally, the seismic hazard for the site studied is defined as the annual probability of exceedance of a certain level of the seismic hazard parameter as a result of the contribution of each one of the sources to the seismic hazard of the site. 
Several methodologies are available for the seismic vulnerability and risk evaluation in urban areas (e.g. Benedetti and Petrini 1984; ATC-13 1985; HAZUS 1999). Thus, the evaluation of the physical seismic vulnerability of structures can be carried out by using: qualitative descriptors (low medium, high, etc. or A, B, C, etc.) as in certain macroseismic scales (MSK-81 1981; Grünthal 1998); physical vulnerability indices like in the vulnerability index method (VIM); and capacity curves (Milutinoviç and Trendafiloski 2003). The expected physical damage can be obtained by using : damage probability matrices, vulnerability functions and fragility curves. It is worth to note that vulnerability and fragility curves allow characterizing the damage of a structure for any severity of the earthquakes while damage probability matrices correspond to a concrete point of the fragility curves (Barbat et al. 2008).

Damage probability matrices, vulnerability functions and fragility curves have been obtained in the past from structural damages observed during earthquakes (Benedetti and Petrini 1984; Kappos et al. 1995; Singhal and Kiremidjian 1996; Barbat et al. 1996). In areas with limited or incomplete data, expert opinions have been used to support or completely replace the probabilistic processing of the observed data (ATC-13 1985; Anagnos et al. 1995). Nonlinear structural analysis procedures have been used as an alternative to the lack or shortage of data (Milutinoviç and Trendafiloski 2003; Barbat et al. 2006a,b). Monte Carlo simulation has been also used to complete the earthquake damage information (Kappos et al.1995; Singhal and Kiremidjian 1996; Barbat et al. 1996, 1998).

The Geologic Institute of Catalonia (IGC) and the International Centre for Numerical Methods in Engineering (CIMNE) participated together with the Municipality of BarceIona in the Risk-UE application to different Mouroux et al. 2004) pplication to the city of Risk-UE project. In the VIM, the seismic action is defined in terms of macroseismic intensity

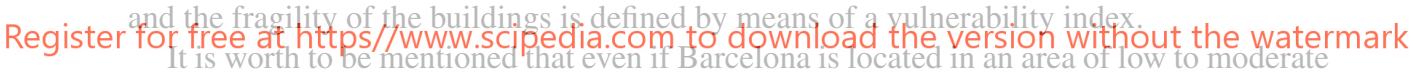
seismic hazard (Egozcue et al. 1991), its buildings have a high degree of vulnerability and, consequently, a significant probability of damage can be expected even in the case of not excessively severe earthquakes.

Although the methodological aspects of this study were mainly developed in the framework of the Risk-UE project, the present article is a compilation of results leading to new high resolution seismic risk scenarios for Barcelona by using the VIM. The results here reported concerning the seismic hazard and the vulnerability of cultural heritage buildings are based on the work of Irizarry (2004) but definitive risk scenarios of the city, including the current buildings, were not available before the work of Lantada (2007), in which a specific GIS platform was developed for the management of a sophisticated data base. The information contained in this database was collected, arranged and improved during more than a decade and it allows calculating and depicting building-by-building risk scenarios for any zone of the city. Updated information about the population of the city and the actual prices of current buildings allowed also assessing the most important aspects concerning the socioeconomic effects. In this way, the VIM has been applied to the studied urban area. Starting from realistic earthquake scenarios and taking into account the seismic zonation of the city, damage probability matrices have been obtained for the four soil types and for more than $95 \%$ of the residential buildings. The main results and conclusions of the study of the seismic risk of the cultural heritage of Barcelona, which considers about 70 monuments of the city, are also a relevant original contribution of this article. 


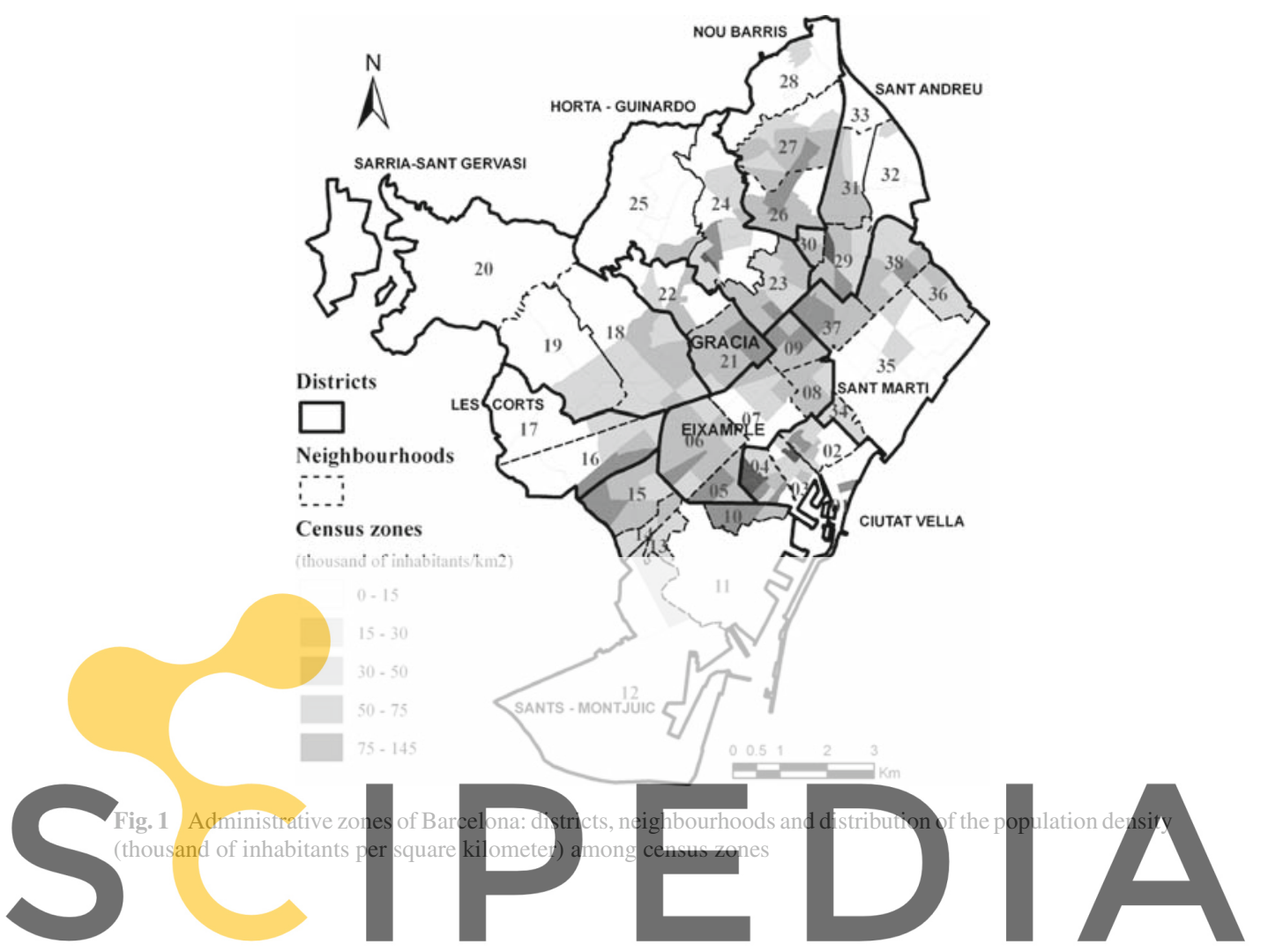

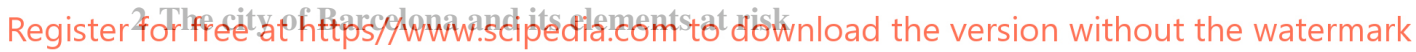

Barcelona, situated on the northeast coast of Spain, is the political and economical capital of Catalonia region and the second city of Spain after Madrid. It has an approximate area of $100 \mathrm{~km}^{2}$ and it concentrates a high percentage of the total population of the region. According to the official statistics of Barcelona (Departament d'Estadistica 2007), in 2006 the city had about 1.606 million inhabitants and an average density of 15,903 inhabitants per square kilometer. According to the Statistic Institute of Catalonia, in 2006 Barcelona had 757,928 housing units, and 75,932 residential buildings, with an average of about 2.53 inhabitants in each. Barcelona is divided into ten districts. Each district consists of a small number of neighbourhoods that sum up to 38 for the entire city. Each neighbourhood is subdivided into census zones (238 in total), as these zones constitute the basis for the census (Fig. 1). These zones are composed by a set of blocks and are used for administrative purposes.

The development of reliable risk scenarios for Barcelona has been possible thanks to the details and quality of the database of the buildings of the city, improved even more during the Risk-UE project. Great amount of information has been collected and completed along years by the Municipality of the city and the Technical University of Catalonia.

\subsection{Residential buildings}

The most important data source, used in the risk assessment at urban scale of Barcelona is the cadastre information. The total number of cadastre units or lots in the city is 80,715 and each 
(a)

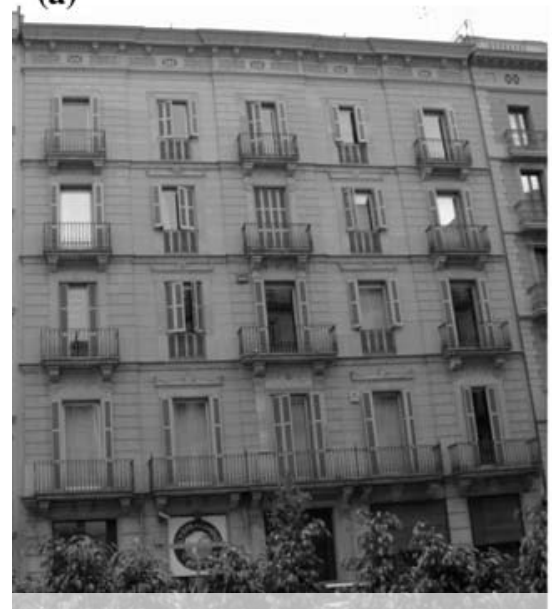

(b)
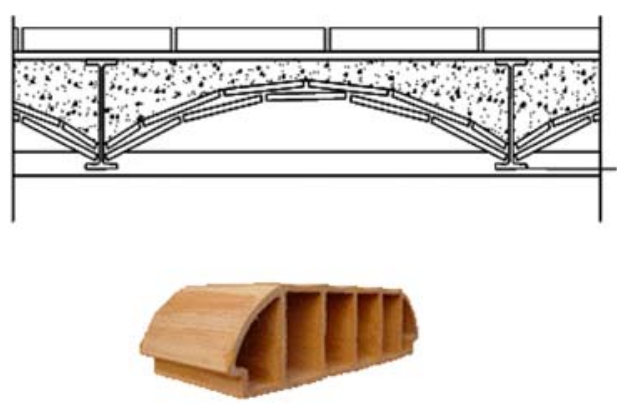

Fig. 2 (a) Traditional unreinforced masonry building, (b) steel beams with ceramic tiles vaults in between (above) and a small ceramic vault (below)

one may contain a building or be empty. This information was used to obtain the geometry and the core features of the buildings of the studied area, like areas and numbers of storeys of each built lot (INHO geometrical features nd state of preservatio number of residential bi residential buildings of Barcelona have been classified in different groups characterized by a similar seismic behaviour. More than 60,600 residential buildings have masonry and reinfor free at https/ www.scipedia.com to download the version without the watermark ranges from 1894 to 1956

The districts of Ciutat Vella and Eixample are the oldest of the city and they show the greatest expected vulnerability and damage. Ciutat Vella means old city and is the downtown of Barcelona, with the oldest buildings; the Eixample district, which means widening, was built in the nineteenth century. This district includes the urban area designed in order to organize the growth of the city between the downtown and the neighbouring small towns or villages. The Eixample district has the maximum average density and some census zones reach a density of 75,000 inhabitants per $\mathrm{km}^{2}$.

The most representative buildings of Ciutat Vella and Eixample districts are unreinforced masonry structures. The majority of these unreinforced masonry buildings are tall and with openings of considerable size and number, which affect their vulnerability, increased even more by long walls without perpendicular stiffening. The floors of these unreinforced masonry buildings are made of wood, steel or of precast concrete beams with small ceramic vaults in between (Fig. 2), showing a poor stiffness both for bending moment and axial forces (Paricio 2001; Castellò and Mañà 2003).

Almost all of these buildings have two storeys due to the considerable difference between height of their ground and first floor (about $4 \mathrm{~m}$ each one), and the others (about $3 \mathrm{~m}$ ) (see Fig. 2a). Similar masonry buildings can also be found in many other European and Mediterranean cities. In some of them, certain seismic protection measures have been applied in the past, but there are also many buildings in such poor conditions that they have to be classified 


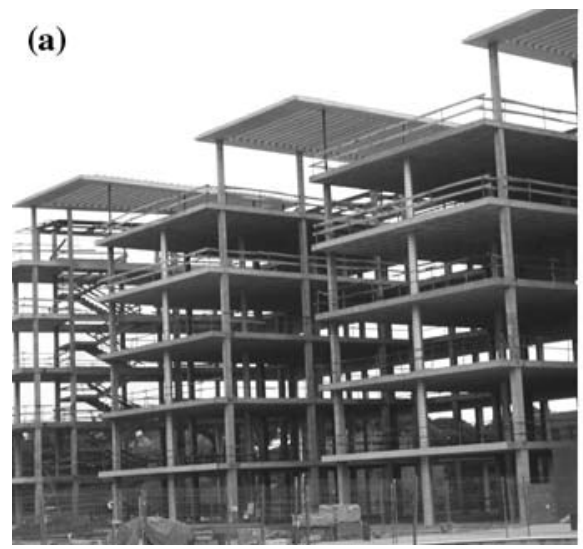

(b)

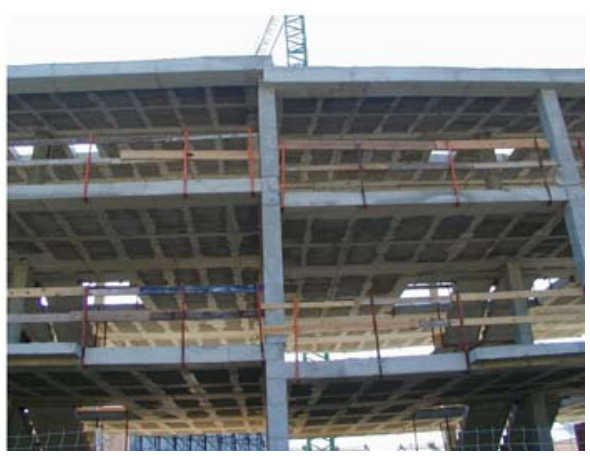

Fig. 3 (a) Reinforced concrete building under construction, (b) typical waffled slabs floors

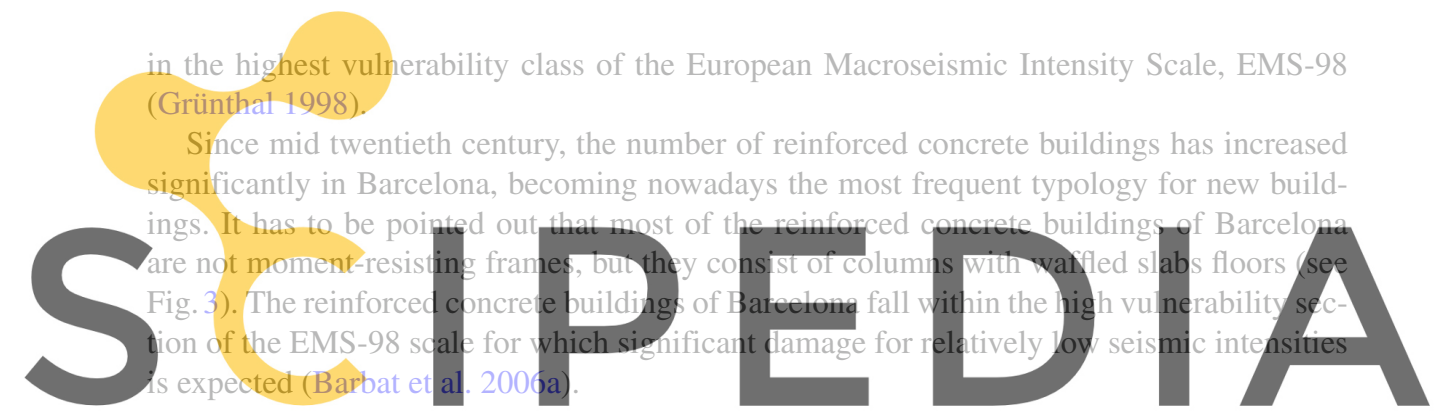

Register for free at httaps//WwW.scipedia.com to download the version without the watermark

The Catalogue of Historic and Artistic Heritage of Barcelona contains a total of 3,400 buildings with the purpose of conserving the characteristic traits of the city. Among these buildings are historical, cultural, religious and architectonic monuments that embrace the cultural and historical heritage of the city of Barcelona. The catalogue classifies the monuments in two levels of protection and only those included in level A of protection were considered in this study. The vulnerability analysis of the 68 monuments of this category was carried out using the vulnerability indices for monumental typologies developed by Lagomarsino et al. (2003). Figure 4 shows their distribution according to the century in which they were built. About $60 \%$ of the monuments were built during the nineteenth and twentieth centuries. Figure 5 shows that the $76 \%$ of all monuments considered are classified as palaces while the rest of monuments are churches, monasteries, theatres, statues, castles and chapels.

\section{Seismic action assessment in terms of intensity for Barcelona}

In the Risk-UE project, it was decided to evaluate the seismic hazard using two different approaches. The first one, called Level I approach, refers to the evaluation of seismic hazard in terms of intensity using a deterministic approach; the Level II approach performs the seismic hazard evaluation in terms of spectral values using both deterministic and probabilistic methods. For the two hazard evaluation approaches considered, site effects have been 
Fig. 4 Century of construction for the studied monuments
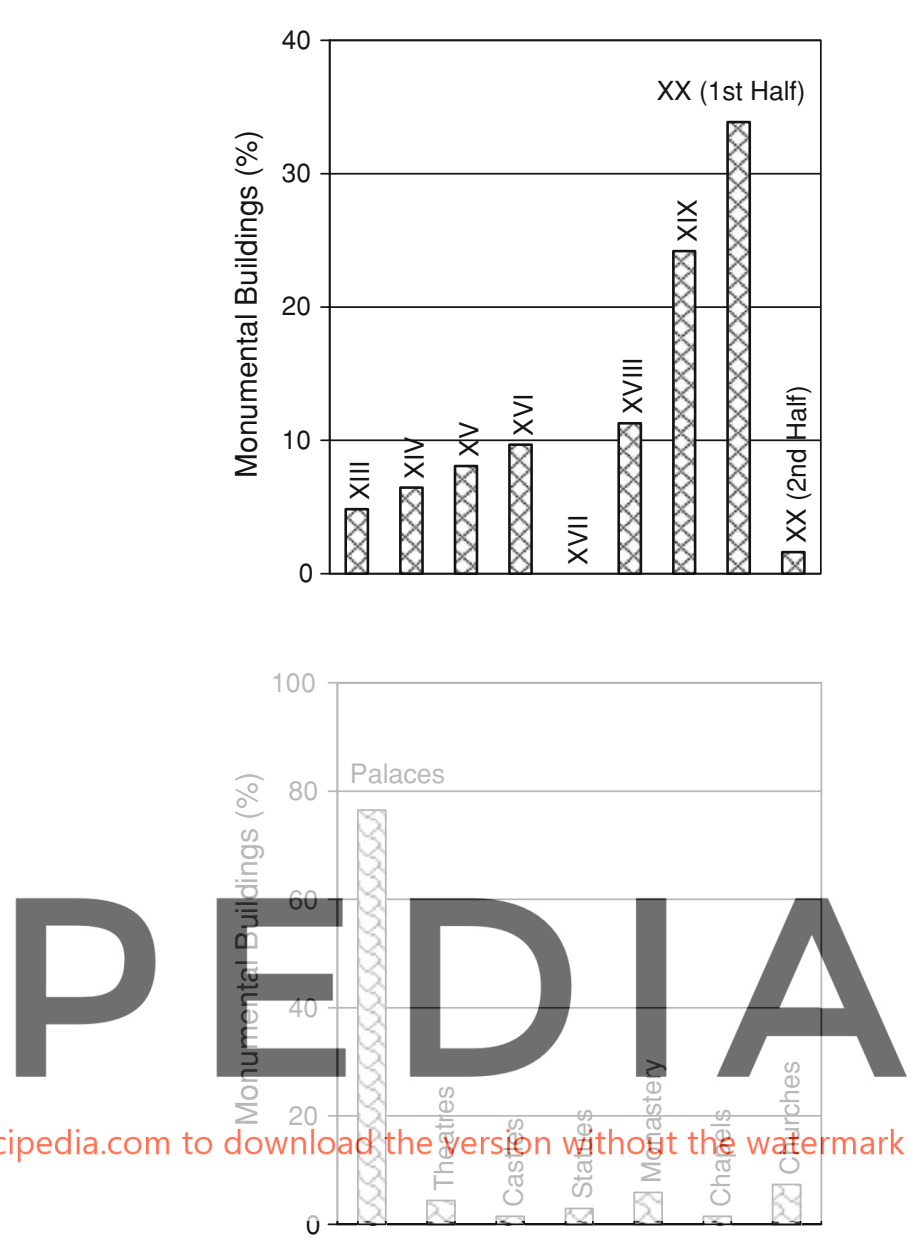

Fig. 5 Monuments distribution according to their typology
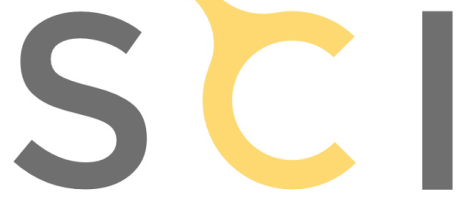

Register for free at https//www.scipedia.com to

evaluated by using a geotechnical zonation of the studied area and by calculating the responses of $1 \mathrm{D}$ linear equivalent model in order to obtain the amplification that can be expected at the studied site (Faccioli 2006).

\subsection{Deterministic seismic scenarios}

The Risk-UE project established guidelines for defining a deterministic hazard scenario in terms of intensity (Faccioli 2006). According to these guidelines, a deterministic scenario without zones is preferred instead of the usual deterministic scenario based on seismic source zones. The deterministic scenario based on seismic source zones allows moving the epicentre of the maximum historical earthquake within the limits of its seismic source zone, to locate it at the closest distance to the studied site. The deterministic scenario without seismic source zones is more representative for the actual seismic history of the region, as it does not change the original location of the maximum historical earthquake considered. The reference earthquake for the city of Barcelona was defined as the closest event with the highest epicentral intensity that had affected the city. This event corresponds to the 1,448 historical 


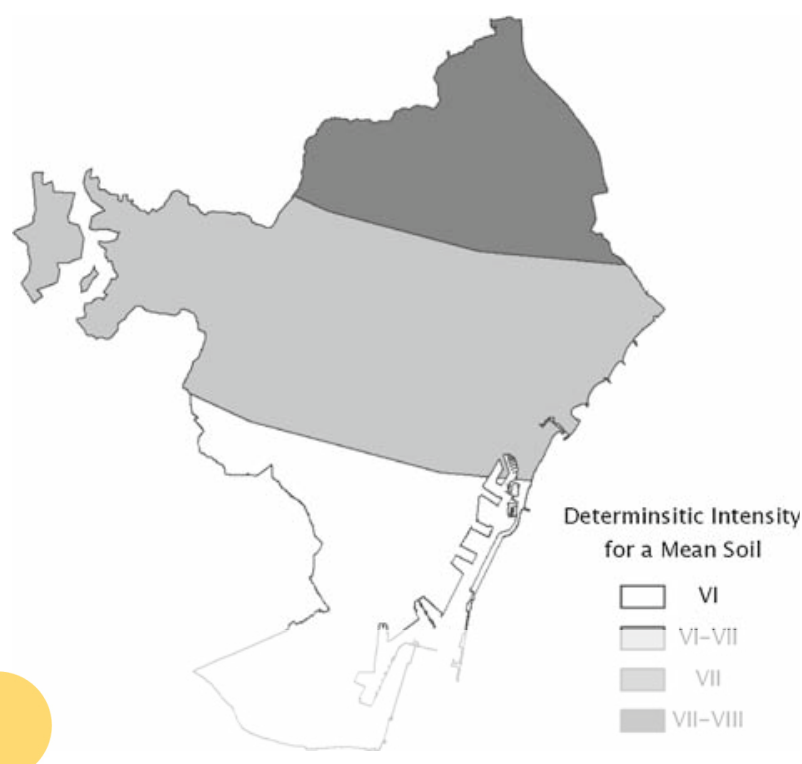

Fig. 6 Deterministic intensity map for mean soil conditions

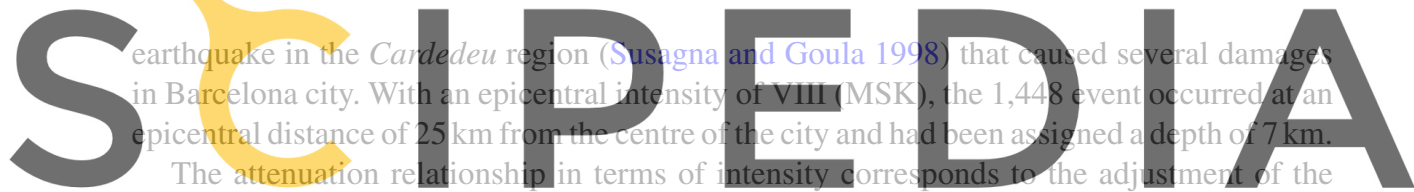

parameters of the Sponheuer (1960) attenuation model using intensity data from Catalonian

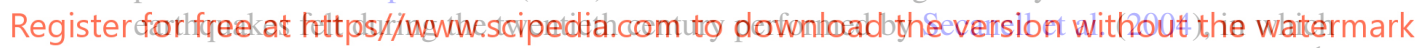
the values of $b, \gamma$ and $k$ for the Catalonia region were stated as $1.0,0.001$ and $3.0 \mathrm{~km}^{-1}$, respectively.

$$
I=I_{0}-k \log _{10}\left(\frac{r}{h}\right)^{b}+k \gamma\left(\log _{10} \mathrm{e}\right)(r-h) \quad r=\sqrt{x^{2}+h^{2}}
$$

The 1,448 earthquake epicentral intensity, $I_{0}$, and the intensity attenuation relationship were used to construct a GIS map with the deterministic intensity expected for a mean soil in the city of Barcelona, shown in Fig. 6. Based on these results, the maximum intensity for a mean soil expected in the city of Barcelona varies from VII degrees to the north of the city to VI degrees in the southern area.

\subsection{Probabilistic seismic scenario}

The assessment of the probabilistic seismic hazard in terms of intensity was not addressed by the Risk-UE project, but the probabilistic seismic hazard for the Catalonian region had been previously obtained in terms of intensity (Secanell 1999; Secanell et al. 2004).

Figure 7 shows the probabilistic seismic hazard in terms of intensity for a return period of 500 years obtained by Secanell et al. (2004) for a mean soil. Based on these results, the city of Barcelona can be expected to be affected by an intensity of VI-VII degrees for a return period of 500 years (an exceedence probability of $10 \%$ in 50 years). For a return period of 500 years, the Spanish Seismic Normative NCSE-02 (2002) assigns to Barcelona a basic acceleration 


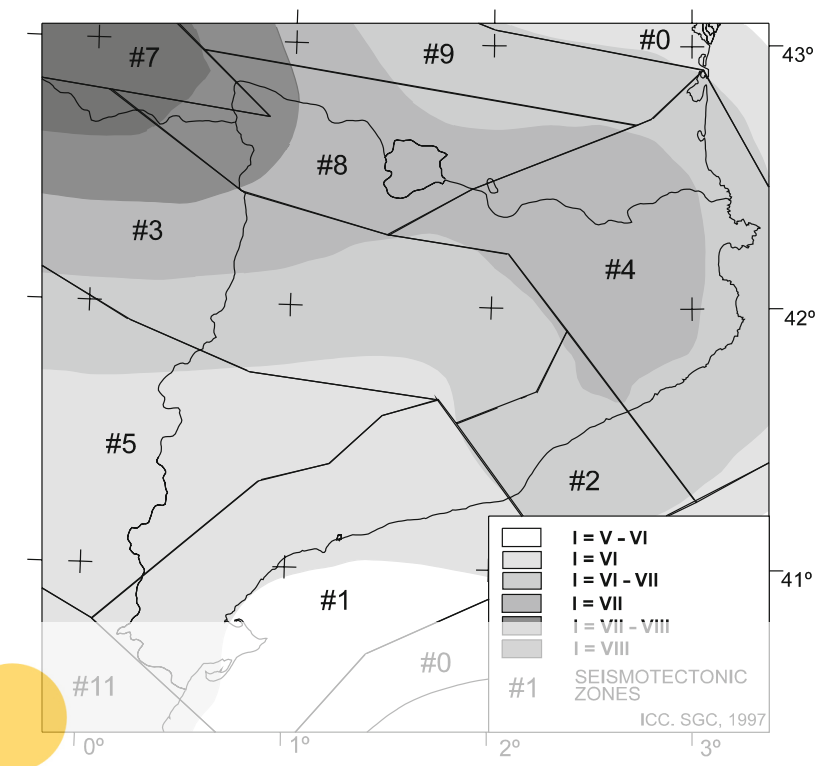

Fig. 7 Probabilistic seismic hazard in terms of intensity for a return period of 500 years for a mean soil (Secanell et al. 2004)
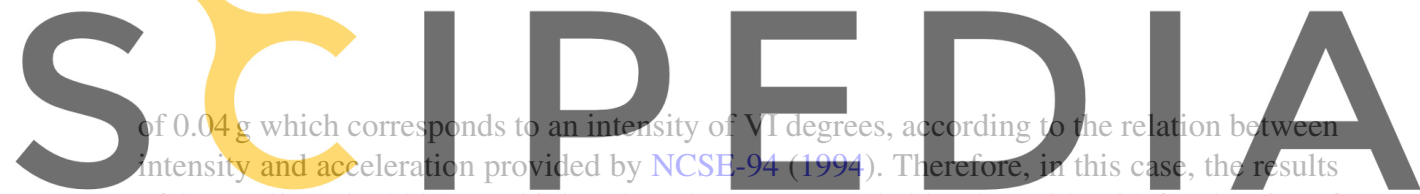

of Secanell et al. (2004) are higher than the recommended by the NCSE-02 for the city of RegisterParcfree at https//www.scipedia.com to download the version without the watermark

\subsection{Seismic scenario assessment with site effects}

The soil effects included in the seismic hazard in terms of intensity are considered following the concepts exposed by Secanell (1999) where a geotechnical characterization of Catalonia by Fleta et al. (1996) was used to apply the soil effects in terms on intensity levels. Depending on the type of soil, the intensity is incremented. The increments used in Secanell (1999) were decided through expert opinions based on empirical correlations like the ones shown in Bard (1997). This way for introducing soil effects in terms of intensity was also recommended within the Risk-UE project (Faccioli 2006).

From Secanell (1999) four soil types where distinguished: hard rock (R), compacted materials (A), semi-compacted materials (B), and non-cohesive material and sands (C). For soil types $\mathrm{R}$ and $\mathrm{A}$, no increment in intensity is applied, while for soil types $\mathrm{B}$ and $\mathrm{C}$ an increment in intensity of 0.5 degrees was applied to construct the deterministic intensity map with soil effects.

Taking into account the seismic zonation of Barcelona based on local effects from Cid et al. (2001) shown in Fig. 8, this increment was applied to soil zones I, II and III. Figure 9a shows the map for deterministic seismic hazard with soil effects in terms of intensity for the city of Barcelona (Irizarry 2004), while Fig. 9b presents the map for the probabilistic seismic hazard for a return period of 500 years including soil effects for the city of Barcelona (Lantada et al. 2008). As can be seen, for both scenarios, the most frequent intensities expected for 


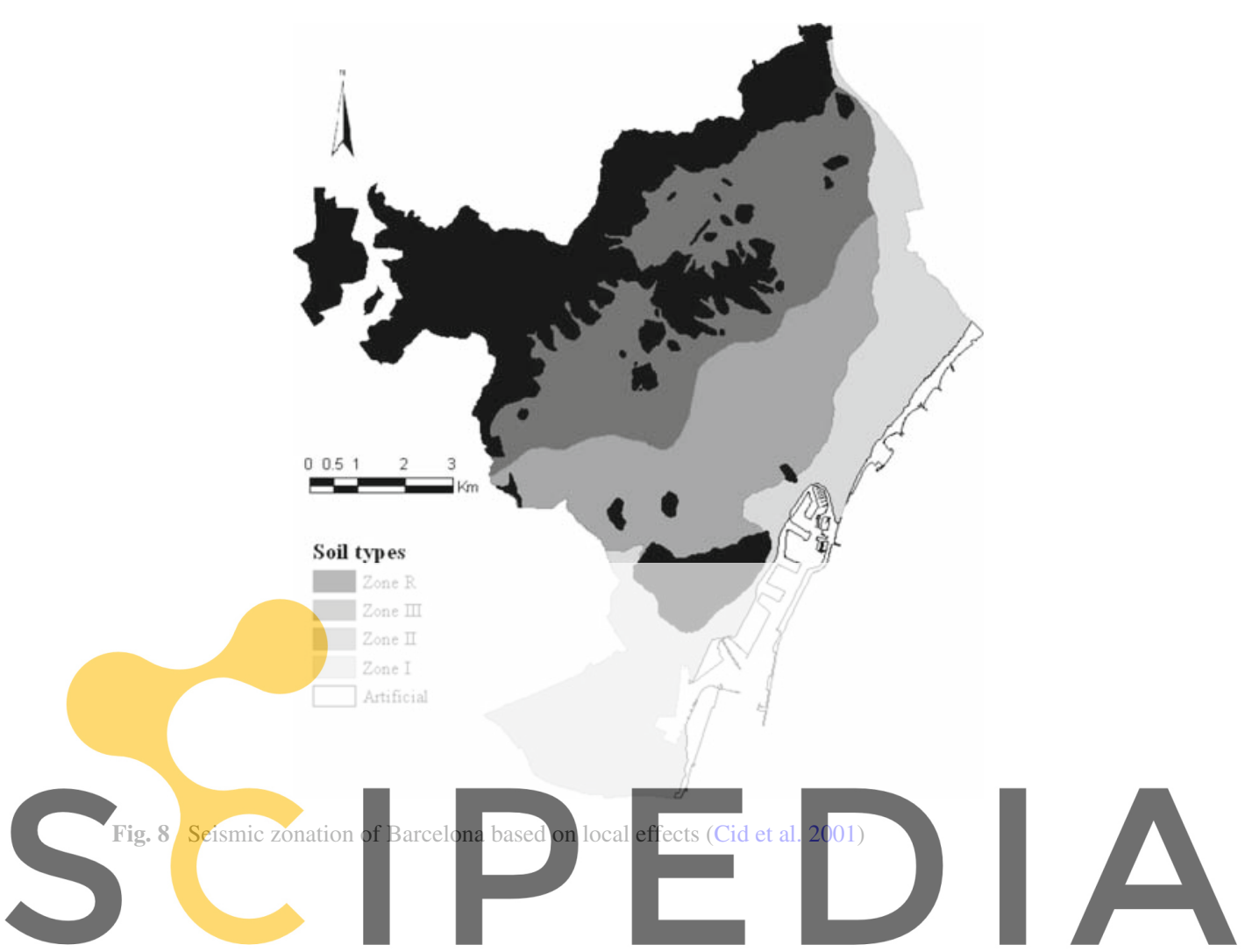

Barcelona are VI-VII and VII. However, in the deterministic scenario, a smaller portion of

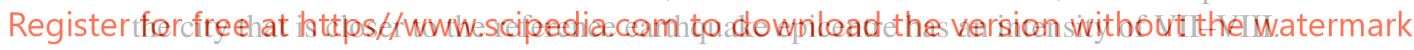

\section{Seismic risk evaluation using the vulnerability index method}

4.1 Vulnerability index method for residential buildings

The VIM proposed by Benedetti and Petrini (1984) was developed based on the extensive damage survey data corresponding to several strong earthquakes in Italy. This method allows identifying differences among buildings with the same structural typology by means of a vulnerability index. Therefore, it has some advantages over the ATC-13 method (ATC-13 1985), which classifies the building according to their typology, material or year of construction. The most important eleven parameters controlling the damage in buildings caused by earthquakes are identified and qualified by means of coefficients affected by weights which try to emphasize their relative importance.

The VIM used in Italy by Gruppo Nazionale per la Defesa dai Terremoti (GNDT 1994; Bernardini 2000) identifies the existing building typologies within an area and defines their class of vulnerability (i.e. A, B, C) (Giovinazzi and Lagomarsino 2002). The VIM version developed in RISK-UE and applied in this article to evaluate the vulnerability and risk of Barcelona is based on observed damage data and on the European Macroseismic Scale EMS'98 classification of buildings (Grünthal 1998). This method requires the seismic action 


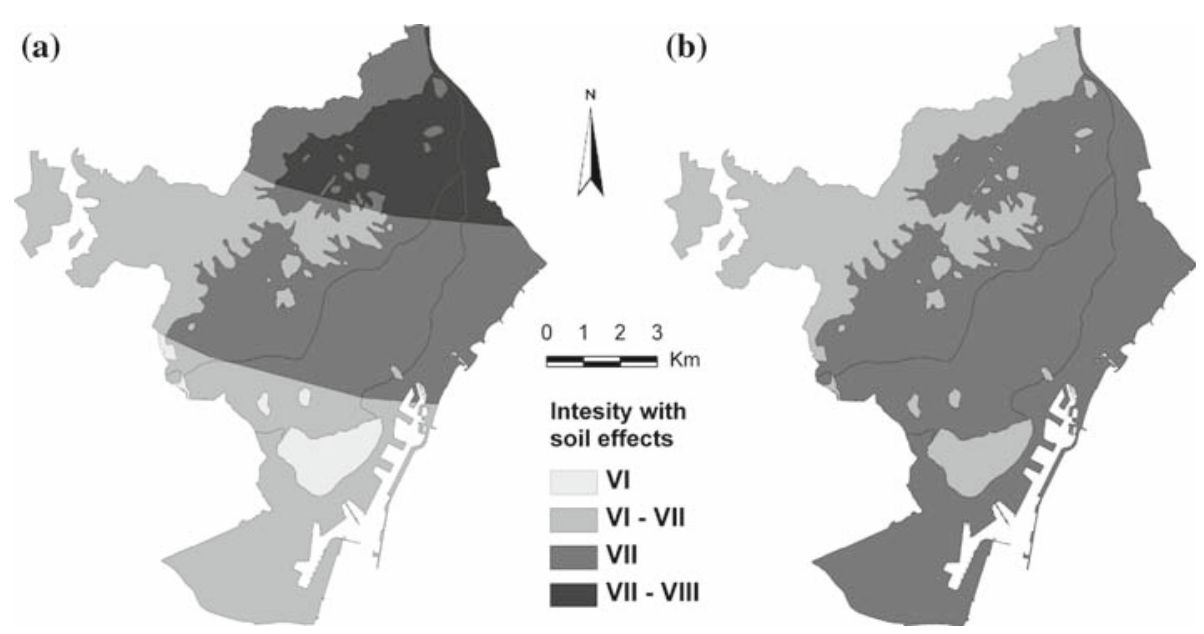

Fig. 9 (a) Deterministic intensity map with site effects for the city of Barcelona (Irizarry 2004). (b) Probabilistic intensity map for a return period of 500 years including site effects for the city of Barcelona (Lantada et al. 2008)

to be defined in terms of macroseismic intensity, the seismic quality of the buildings to be described by means of a vulnerability index, and it makes use of the classical probability theory and of the fuzzy-set theory (Giovinazzi and Lagomarsino 2002; Lagomarsino and Giovinazzi 2006). According to the fuzzy set theory, the trapezoidal membership functions $\chi$ of the six vulnerability classes have a plausible $(\chi=1)$ and two linear possible ranges, defining the transition between two adjacent classes. $V_{I}^{*}$ is the most probable or plausible value of the vulnerability index $(\chi=1) ;\left[V_{I}^{-} ; V_{I}^{+}\right]$are bounds of the plausible range of the vulnerability index $(\chi=0.6) ;\left[V_{I}^{\min } ; V_{I}^{\max }\right]$ are upper and lower bounds of the possible values $(\chi=0.2)$ (Table 1$)$.

The Risk-UE VIM establishes a typological classification system in order to group structures with a similar seismic behaviour. Table 1 shows vulnerability indices for some of theses typologies through the building typology matrix or BTM, which essentially corresponds to that adopted by EMS-98.

The vulnerability index has been conventionally defined ranging from -0.02 to 1.02 (Lagomarsino and Giovinazzi 2006). However, vulnerability indices are normalized taking values between 0 (least vulnerable buildings) and 1 (most vulnerable buildings). The method identifies the existing building typologies within the studied area and defines their vulnerability class. For each vulnerability class, the relationship between intensity and damage is defined by using damage probability matrices (DPM) (Whitman 1973).

Further refinements of the vulnerability index $V_{I}$ come from behaviour modifiers which are used to evaluate a final vulnerability index of each building $V_{I}^{\text {building }}$ as follows:

$$
V_{I}^{\text {building }}=V_{I}^{\text {class }}+\Delta M_{R}+\sum_{j=1}^{n} \mathrm{Vm}_{j}
$$

where $V_{I}^{\text {class }}$ is the vulnerability index corresponding to the category of the building, $\Delta M_{R}$ is a regional modifier which takes into account the peculiarities of the region or building period while $\mathrm{Vm}_{j}$ are vulnerability factors or behaviour modifiers that incorporate other aspects of 
Table 1 Vulnerability index values for several cases of the building typology matrix, BTM, proposed by Risk-UE (Milutinoviç and Trendafiloski 2003)

\begin{tabular}{|c|c|c|c|c|c|c|}
\hline \multirow[t]{2}{*}{ Typology } & \multirow[t]{2}{*}{ Description } & \multicolumn{5}{|c|}{ Vulnerability indices } \\
\hline & & $V_{I, \mathrm{BTM}}^{\min }$ & $V_{I, \mathrm{BTM}}^{-}$ & $V_{I, \mathrm{BTM}}^{*}$ & $V_{I, \mathrm{BTM}}^{+}$ & $V_{I, \mathrm{BTM}}^{\max }$ \\
\hline M3.1 & $\begin{array}{l}\text { Unreinforced masonry bearing walls } \\
\text { with wooden slabs }\end{array}$ & 0.460 & 0.650 & 0.740 & 0.830 & 1.020 \\
\hline M3.2 & $\begin{array}{l}\text { Unreinforced masonry bearing walls } \\
\text { with Masonry vaults }\end{array}$ & 0.460 & 0.650 & 0.776 & 0.953 & 1.020 \\
\hline M3.3 & $\begin{array}{l}\text { Unreinforced masonry bearing walls } \\
\text { with composite steel and masonry } \\
\text { slabs }\end{array}$ & 0.460 & 0.527 & 0.704 & 0.830 & 1.020 \\
\hline M34 & Reinforced concrete slabs & 0.300 & 0.490 & 0.616 & 0.793 & 0.860 \\
\hline $\mathrm{RC} 3.1$ & $\begin{array}{l}\text { Concrete frames with regular unrein- } \\
\text { forced masonry infill walls }\end{array}$ & 0.460 & 0.650 & 0.740 & 0.830 & 1.020 \\
\hline $\mathrm{RC} 3.2$ & $\begin{array}{l}\text { Concrete frames with unreinforced } \\
\text { masonry infill walls with irregularly } \\
\text { frames (i.e. irregular structural sys- } \\
\text { tem, irregular infills, soft/weak story) }\end{array}$ & 0.060 & 0.127 & 0.522 & 0.880 & 1.020 \\
\hline $\mathrm{S} 1$ & Steel moment frames & -0.020 & 0.467 & 0.363 & 0.640 & 0.860 \\
\hline $\mathrm{S} 2$ & Steel braced frames & -0.02 & 0.467 & 0.287 & 0.480 & 0.700 \\
\hline S3 & $\begin{array}{l}\text { Steel frames with unreinforced } \\
\text { masonry infill walls }\end{array}$ & 0.140 & 0.330 & 0.484 & 0.640 & 0.860 \\
\hline S4 & $\begin{array}{l}\text { Steel frames with cast-in-place } \\
\text { concrete shear walls }\end{array}$ & -0.02 & 0.047 & 0.224 & 0.350 & 0.540 \\
\hline S5 & Steel and RC composite systems & -0.020 & 0.257 & 0.402 & 0.720 & 1.020 \\
\hline W & Wood structures & 0.140 & 0.207 & 0.447 & 0.640 & 0.860 \\
\hline
\end{tabular}

$V_{I}^{*}$ is the most probable or plausible value and $V_{I}^{-} / V_{I}^{+}$and $V_{I}^{\min } / V_{I}^{\max }$ are the probable and less probable vulnerability index ranges, respectively

the building affecting its seismic behaviour. Two kinds of $\mathrm{Vm}_{j}$ modifiers are considered in Eq. (2): building modifiers and location modifiers.

This RISK-UE VIM version uses six damage states: a no-damage state (denoted as None), Slight, Moderate, Substantial to Heavy, Very Heavy and Destruction (Grünthal 1998). A sort of mean damage grade, $\mu_{D}$, permits to characterize completely the expected damage for a building, known its vulnerability $\left(V_{I}\right)$ and for a given intensity $(I)$ by the following equation:

$$
\mu_{D}=2.5\left[1+\tanh \left(\frac{I+6.25 V_{I}-13.1}{\phi}\right)\right]
$$

The parameter $\phi$ in Eq. (3) is the ductility index, which is evaluated taking into account the building typology and its constructive features (Lagomarsino and Giovinazzi 2006); it controls the slope of the curves and assumes different values to fit the data obtained through damage surveys. For residential buildings, it takes a value of 2.3. Then, damage probability matrices can be easily obtained by assuming that the damage probability follows a binomial or beta-equivalent probability distribution (Giovinazzi and Lagomarsino 2002).

A weighted mean damage index, $\mathrm{DS}_{m}$, can be calculated by using the following equation:

$$
\mathrm{DS}_{m}=\sum_{k=0}^{5} k P\left[\mathrm{DS}_{k}\right]
$$


Table 2 Values of the vulnerability index and ductility index for monument typologies (Lagomarsino et al. 2004)

\begin{tabular}{lllll}
\hline Monument typology & \multicolumn{2}{l}{ Vulnerability index, $V_{I}$} & \multirow{2}{*}{ Ductility index, $\phi$} \\
\cline { 2 - 4 } & Lower & Mean & Upper & \\
\hline Palaces/buildings & 0.496 & 0.616 & 0.956 & 2.3 \\
Monasteries & 0.616 & 0.736 & 1.076 & 2.3 \\
Castles & 0.356 & 0.456 & 0.766 & 2.3 \\
Churches & 0.770 & 0.890 & 1.260 & 3.0 \\
Chapels/oratories & 0.650 & 0.770 & 1.140 & 3.0 \\
Mosques & 0.670 & 0.730 & 0.940 & 2.65 \\
Theatres & 0.616 & 0.736 & 1.086 & 2.65 \\
Towers & 0.636 & 0.776 & 1.136 & 2.3 \\
Bridges & 0.216 & 0.296 & 0.566 & 2.3 \\
Walls & 0.396 & 0.496 & 0.746 & 2.3 \\
Triumphal arches & 0.376 & 0.456 & 0.706 & 2.3 \\
Obelisks & 0.396 & 0.456 & 0.746 & 1.95 \\
Statues/fountains & 0.236 & 0.296 & 0.606 & 1.95 \\
\hline
\end{tabular}

where $k$ takes the values $0,1,2,3,4$ and 5 for the damage states $k$ considered in the analysis and $P\left(\mathrm{DS}_{k}\right)$ represents the corresponding probabilities of occurrence for the damage state $k$. It can be considered that $\mathrm{DS}_{m}$ is close to the most likely damage state of the structure. This damage index is equivalent to the mean damage grade, $\mu_{D}$, and it is useful for mapping and analyzing damage distributions by using a single parameter. Of course, alternative maps may plot the spatial distribution of the probability of occurrence of a specified damage state $\mathrm{DS}_{k}$, that is $P\left(\mathrm{DS}_{k}\right)$.

\subsection{Vulnerability index method for monumental buildings}

Within the Risk-UE project, vulnerability indices were also developed for monumental buildings. From the structural point of view, many monuments are special and unique structures that cannot be fitted into the typologies proposed by Milutinoviç and Trendafiloski (2003) for residential buildings. For these reason, Lagomarsino et al. (2004) recommends the application of the VIM using a different set of typologies, shown in Table 2, that are not necessarily related to the structural system of the monument. The characterization of the seismic behaviour of some of the monumental typologies was made using statistical analysis of observed damages, like in the case of buildings and churches. Numerous statistical data was available for ancient buildings and churches from damage surveys performed during the Friuli (1976) and Umbria-Marche (1996-1997) earthquakes (Lagomarsino 2006). Like no observed damage data was available for all other monument typologies, Lagomarsino (2006) derived its vulnerability indices based on expert knowledge and using the vulnerability curves developed for churches and buildings as reference.

The variability of the vulnerability indices was also considered, and therefore their upper and lower limits are also given in Table 2 for each typology. The highest vulnerability index belongs to the churches but towers, chapels, oratories, monasteries, theatres, mosques, palaces and buildings also are very vulnerable as it can be seen in Fig. 10. 


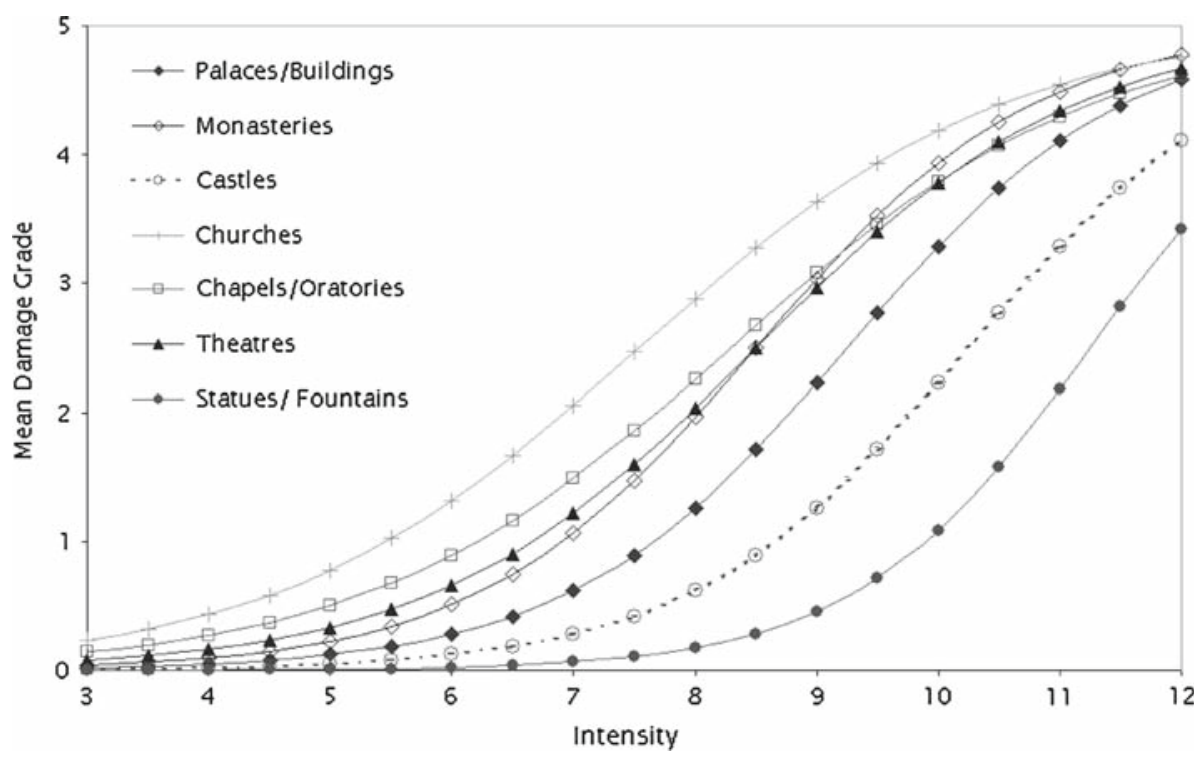

Fig. 10 Mean vulnerability curves for the different monument typologies

After assigning a vulnerability index to a monument as a function of a given typology, the monument vulnerability is modified in function of the specific characteristics of the monumental building using vulnerability modifier specifically defined for monuments (Lagomarsino 2006). The final vulnerability index of each monument is used to calculate its expected mean damage grade using the vulnerability function shown in Eq. (3).

\section{Seismic risk scenarios for the city of Barcelona}

All the available data have been integrated into a geographic information system (GIS) which, in this case, was ArcView GIS. This tool and the information on the city allowed performing a building by building analysis. However, in order to display the results in a clearer way, the building by building results have been summarized using the administrative zones of the city (especially census zones).

\subsection{Physic direct damage for residential and monumental buildings}

According to the classification of buildings proposed in handbook of Workpackage 1 of Risk-UE Project (Lungu et al. 2001) (see Table 1), the predominant typologies in Barcelona are the masonry with wooden slabs M3.1 (16,972 buildings) and the masonry with composite steel and masonry slabs M3.3 (15,389 buildings). Further refinements of the vulnerability index $V_{I}$ come from behaviour modifiers, which are used to evaluate a global vulnerability index of each building according to Eq. (2). Table 3 shows the Vulnerability Index $V_{I}^{\text {class }}$ modified with $\Delta M_{R}$ based on earthquake resistant considerations and on the seismic codes changes produced in Spain. The buildings have been classified into different ranges of the year of construction. Almost the $80 \%$ of the building stock of Barcelona was constructed prior to the implementation of the first Spanish Seismic Code (PGS-1 1968). 
Table 3 Vulnerability index for building typologies and periods of construction according to the Spanish seismic code level

\begin{tabular}{llllllll}
\hline $\begin{array}{l}\text { Period of } \\
\text { construction }\end{array}$ & $\begin{array}{l}\text { Spanish seismic } \\
\text { code }\end{array}$ & $\begin{array}{l}\text { Lateral bracing in } \\
\text { constructive } \\
\text { practice }\end{array}$ & $\begin{array}{l}\text { Code } \\
\text { level }\end{array}$ & $\begin{array}{l}\text { Buildings } \\
(\%)\end{array}$ & $\begin{array}{l}\text { Vulnerability } \\
\left(V_{I}\right)\end{array}$ & index \\
\cline { 4 - 7 } & & & & $\begin{array}{l}\text { M3.1 } \\
\text { M3.2 } \\
\text { M3.3 }\end{array}$ & M3.4 & RC3.2 \\
\hline Before 1950 & - & Absent & Pre-code & 50.7 & 0.94 & - & - \\
$1950-1962$ & - & Peficient & Pre-code & 17.3 & 0.88 & - & - \\
$1963-1968$ & Recommendation & Deficient & Pre-code & 10.9 & 0.81 & 0.75 & 0.75 \\
$1969-1974$ & $\begin{array}{l}\text { MV101 (1963) } \\
\text { Seismic code }\end{array}$ & Acceptable & Low & 9.8 & 0.75 & 0.63 & 0.63 \\
$1975-1994$ & $\begin{array}{l}\text { PGS-1 (1968) } \\
\text { Seismic code }\end{array}$ & Acceptable & Low & 11.1 & 0.69 & 0.56 & 0.50 \\
1995 untilnow & $\begin{array}{l}\text { PDS-1 (1974) } \\
\text { Seismic code }\end{array}$ & Acceptable & Low & 0.2 & 0.69 & 0.56 & 0.50 \\
\hline
\end{tabular}

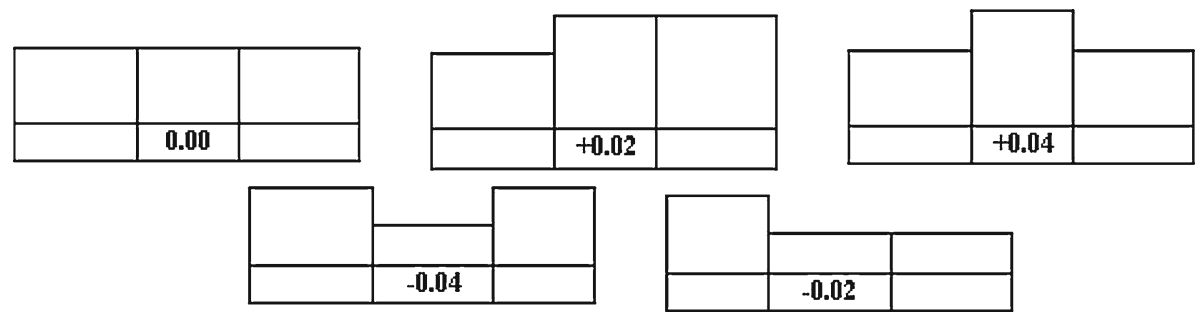

Fig. 11 Location modifiers for each building according to the difference between its height and the height of the two adjacent buildings

The building modifiers refer to isolated buildings, quantifying: the number of floors; the preservation state; vertical irregularity that depends on the areas with different number of floors in the building; the length of the façade of masonry buildings with façades longer than $15 \mathrm{~m}$; and horizontal irregularity that is based on the compactness ratio $\mathrm{RC}$ of the building (Udwin 1981) according to the following equation:

$$
\mathrm{RC}=\sqrt{\frac{A}{A_{C}}}
$$

where $A$ is the area of the building and $A_{C}$ the area of the circle with the same perimeter that the building. The value of $\mathrm{RC}$ is equal to 1 for circular buildings and ranges from 1 to 0 for other shapes. This modifier takes values of 0.02 and 0.04 units for buildings with RC values lower than 0.7 and 0.5 , respectively.

The location modifiers that take into account: the difference in height between each building and the adjacent buildings, but only when this difference is greater than or equal to two floors (Fig. 11); and the position of buildings in the aggregate or the block they belong. Particularly, this modifier penalises corner buildings and buildings located at the ends of an aggregate, increasing their vulnerability index in 0.04 and 0.06 units, respectively. The vulnerability index of buildings placed in the middle of the aggregates is reduced in 0.04 units. 

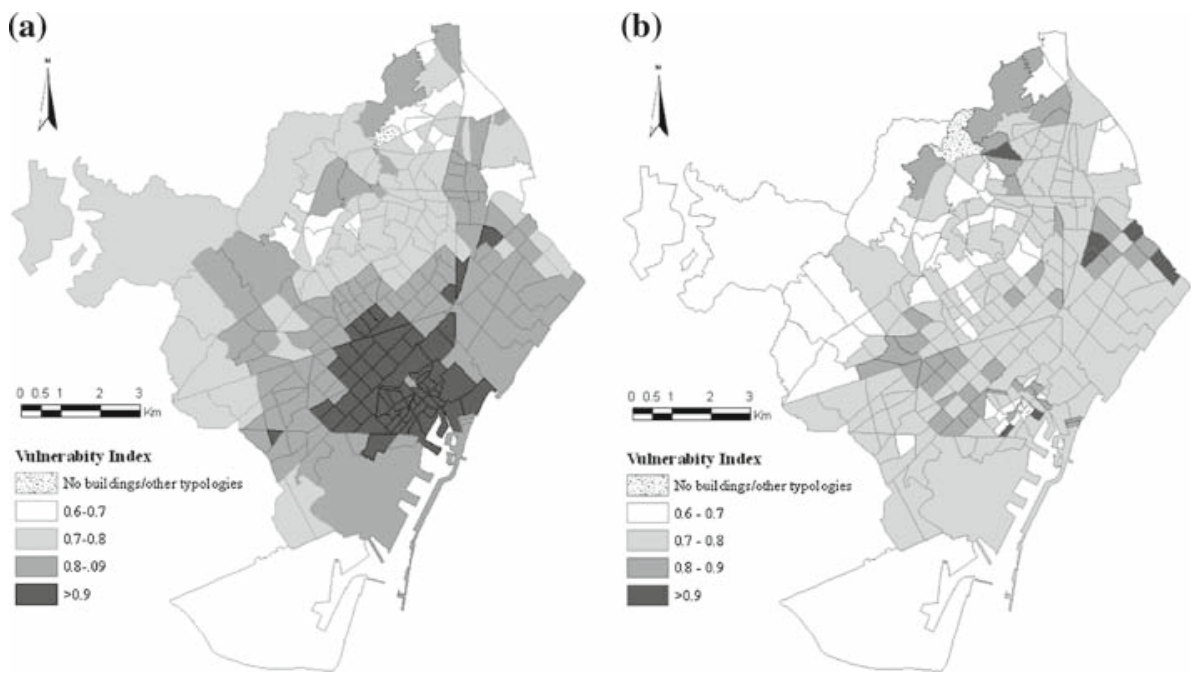

Fig. 12 Mean vulnerability indices by census zones for (a) masonry buildings and (b) reinforced concrete buildings

The vulnerability indices of masonry buildings show values ranging from 0.7 to almost 1 , with a mean value of 0.87 , while indices in reinforced concrete buildings are smaller, ranging from 0.4 to 0.85 (mean value of 0.65 ). The mean vulnerability index of masonry and reinforced concrete buildings obtained for each census zone is shown in Fig. 12a, b, respectively. In the first case a radial pattern is observed, with the greatest vulnerability indices located in the historic city centre. Many old buildings with a deficient seismic quality are concentrated downtown. In the second figure a slight decrease on vulnerability can be observed but the radial pattern has disappeared. This vulnerability analysis shows the low seismic quality of the residential buildings in the city, which is typical of those cities located in areas with low to moderate hazard because there is no concern about the seismic hazard that affect them.

The mean damage grade for each district can be seen in Fig. 13 for both the deterministic and probabilistic hazard scenarios. The distribution of damage follows a radial pattern from downtown to the outskirts of Barcelona. A higher damage in the proximity of the epicentre of the considered earthquake (northern part of the city) is observed in the deterministic hazard case of Fig. 13a.The mean damage grade $\mu_{D}$ for the entire city (Eq. 3) is 1.65 and 1.59 for the deterministic and probabilistic hazard scenario, respectively, which correspond in both cases, to a moderate damage state according to Table 4 . In both cases, the highest damage expected is located in the downtown, for which damages close to Substantial to Heavy (a value 2.4 for the mean damage index) can be expected in both cases.

The selected monumental buildings were integrated in the GIS system to determine the level of intensity affecting them according to the deterministic scenario based on the 1,448 Cardedeu earthquake. The distribution of monuments according to the level of intensity expected to affect them, shows that 51 of the 68 monuments are expected to experience an intensity of VII degrees when soil effects are considered, while only a few of them would be affected by an intensity VII-VIII.

An inventory of the 68 monumental buildings included in the level A of protection was carried out, gathering all the possible information in order to evaluate their vulnerability 

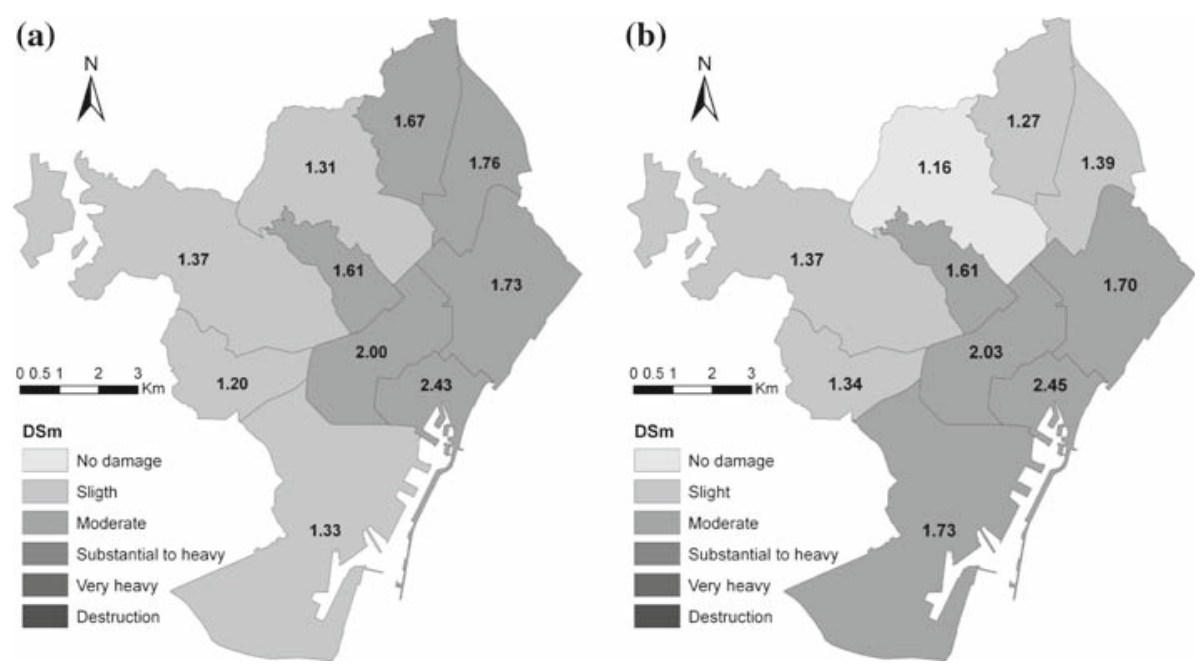

Fig. 13 Mean damage grade for each district for (a) deterministic seismic hazard scenario (b) probabilistic seismic hazard scenario

Table 4 Mean damage index values and damage states

\begin{tabular}{ll}
\hline Mean damage index intervals $\left(\mathrm{DS}_{m}\right)$ & Most probable damage state \\
\hline $0.0-0.5$ & None \\
$0.5-1.5$ & Slight \\
$1.5-2.5$ & Moderate \\
$2.5-3.5$ & Substantial to heavy \\
$3.5-4.5$ & Very heavy \\
$4.5-5.0$ & Destruction \\
\hline
\end{tabular}

considering the maximum possible number of modifiers. Figure 14 shows the distribution of monuments according to their final vulnerability index for the three levels considered. For both, the lower and mean values of the vulnerability index, the greater part of the monumental buildings considered has a vulnerability index between 0.50 and 0.70 . For the upper values of the vulnerability index, the $81 \%$ of the monumental buildings have a vulnerability index between 0.90 and 1.1. The intervals of vulnerability index with the higher number of monuments correspond to those intervals containing the palace vulnerability index, the most abundant typology of the monuments set considered. The dispersion of the obtained vulnerability index distributions is large due to the differences between the lower, mean and upper values of the initial vulnerability indices shown in Table 2.

Once the vulnerability indices were obtained for each monument, the expected mean damage, $\mu_{d}$, was calculated for each monument using the lower, mean and upper vulnerability indices. As expected, churches, monasteries, chapels and theatres show the higher levels of mean damage grade. Maximum mean damage grades of 2, 3 and 4 were obtained using the lower, mean and upper vulnerability indices, respectively.

The percentage of monumental buildings expected to have a given mean damage grade is shown in Fig. 15 for the considered values of the vulnerability indices (lower, mean and upper). Once again, great differences are observed between the mean damage distributions 
Fig. 14 Distribution of monuments based on their vulnerability index

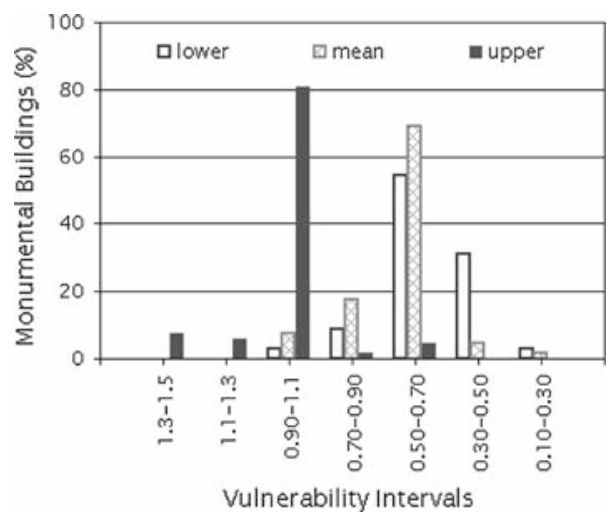

Fig. 15 Monuments distribution according to their mean damage grade

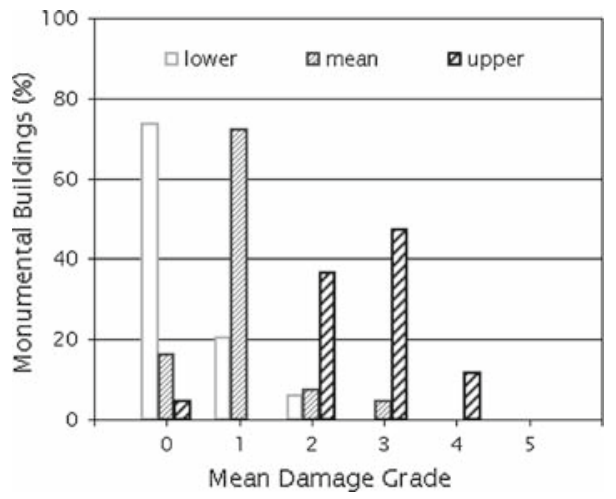

due to the dispersion presented by the lower, mean and upper values of the vulnerability indices proposed by Lagomarsino et al. (2004). Considering the mean values of the vulnerability index, over $70 \%$ of the monuments are expected to have a mean damage grade of 1 , or a mean damage grade of 0 if the lower vulnerability indices are used. Based on the upper vulnerability indices, the majority of the monuments are expected to have mean damage grade of between 2 and 3 but there is a 12\% with a mean damage grade of 4 implying very heavy damages.

Figure 16 shows the ten monuments with the highest values for the mean damage grade. Using the mean and lower values of the vulnerability index, some monuments obtained mean damage grades of 2 and close to 3, meaning that light to medium damages can be expected in their structures. Due to the nature of many monuments, even minor damages can imply loosing their patrimonial value. Using the upper limits, the higher mean damage grades grow up to passed 4 . Some monuments can even have a probability of collapsing due to their high mean damage grade.

As the mean damage grade represents a damage distribution, damage probabilities can be calculated for each mean damage grade of each monument. Damage probability distributions for each monument using the lower, mean and upper values of the vulnerability indices have been calculated using the binomial distribution (Irizarry et al. 2004). As examples, the damage distributions for the Sagrada Familia and the Santa Maria del Mar churches are shown in Fig. 17. Based on the upper values of the vulnerability indices, these two monuments have the collapse condition as the most probable damage grade. For the mean and lower values of 


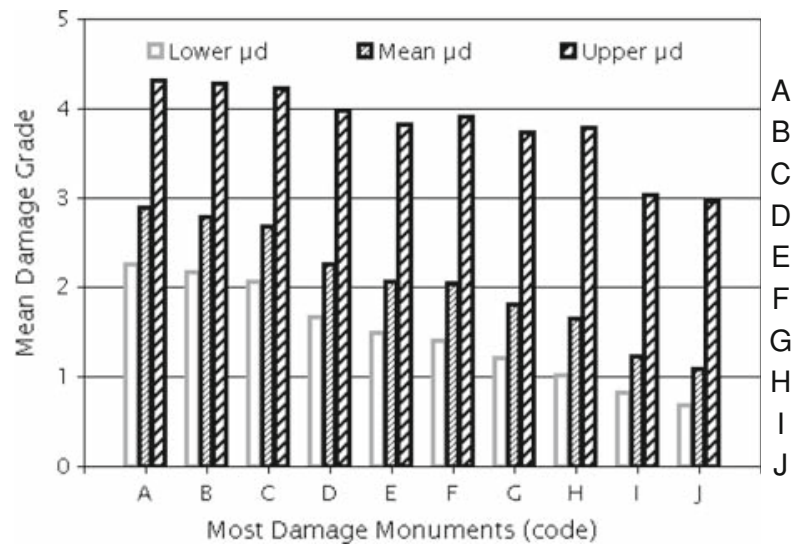

A Sagrada Familia

Església Sta Maria del Mar

Església Sta Maria del Pi

Església Betlem

Catedral de Barcelona

Ateneu Barcelonès

Palau de la Musica Catalana

Monestir Sant Pau del Camp

Capella Sta Agueda

Gran Teatre del Liceu

Fig. 16 Monuments with the highest mean damage grade
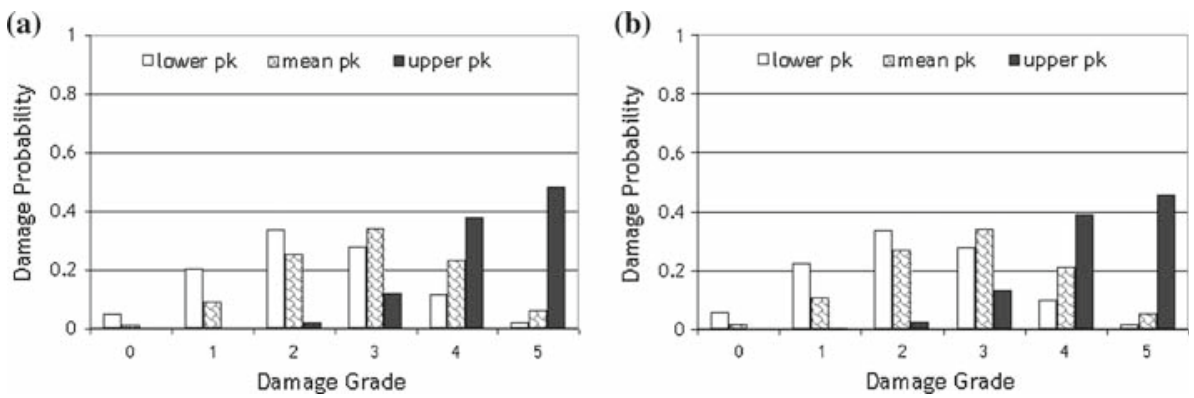

Fig. 17 Damage distributions for Sagrada Familia (left) and Santa María del Mar (right) churches

the vulnerability indices, the collapse probability (damage grade 5), although being small, is not negligible.

The expected damage for the Santa María del Mar church was also evaluated by Irizarry et al. (2004) using the capacity spectrum method and considering the same deterministic scenario based on the 1,448 Cardedeu Earthquake. Results from the capacity spectrum method reveal that a slight to moderate damage condition can be expected for this church under such hazard scenario. The mean damage grade obtained using the VIM is 2.78, which is between damage grades 2 and 3 that correspond to of light and moderate damage conditions, respectively. So, the results from the two methods are quite similar. In addition this church suffered damages during the 1,373 historical earthquake when it was still under construction (Olivera et al. 1994). The description of these damages also corresponds to a slight to moderate damage conditions.

\subsection{Damage to population}

The direct physical damage obtained is the starting point for other aspects of risk, such as damage to population, institutions and services, as well as to the economical and social system functions of the city. ATC-13 (1985), Coburn and Spence (2002) and Vacareanu et al. (2004) provide models to incorporate to the physical risk analysis, the number of casualties and 
Table 5 Distribution of the population by districts for Scenario 1 (a working day in winter) and Scenario 2 (day or night of a winter holiday) (Martí 2000)

\begin{tabular}{|c|c|c|c|c|c|}
\hline \multirow[t]{2}{*}{ Districts } & \multirow[t]{2}{*}{ Population 1996} & \multicolumn{2}{|c|}{$\begin{array}{l}\text { Scenario 1. population in } \\
\text { buildings }\end{array}$} & \multicolumn{2}{|c|}{$\begin{array}{l}\text { Scenario 2. population in } \\
\text { buildings }\end{array}$} \\
\hline & & $\begin{array}{l}\text { Thousand of } \\
\text { inhabitants }\end{array}$ & Percentage & $\begin{array}{l}\text { Thousand of } \\
\text { inhabitants }\end{array}$ & Percentage \\
\hline 1. Ciutat Vella & 83800 & 122.0 & 145.58 & 75.5 & 90.10 \\
\hline 2. Eixample & 248800 & 344.8 & 138.59 & 175.8 & 70.66 \\
\hline 3. Sants-Montjuïc & 167400 & 209.2 & 124.97 & 149.0 & 89.01 \\
\hline 4. Les Corts & 81900 & 137.2 & 167.52 & 54.0 & 65.93 \\
\hline 5. Sarrià-St. Gervasi & i 129600 & 143.2 & 110.49 & 88.3 & 68.13 \\
\hline 6. Gràcia & 115800 & 115.9 & 100.09 & 89.5 & 77.29 \\
\hline 7. Horta-Guinardó & 169800 & 153.3 & 90.28 & 141.1 & 83.10 \\
\hline 8. Nou Barris & 170800 & 133.9 & 78.40 & 143.6 & 84.07 \\
\hline 9. Sant Andreu & 135600 & 130.4 & 96.17 & 116.2 & 85.69 \\
\hline 10. Sant Martí & 205400 & 185.0 & 90.07 & 167.0 & 81.30 \\
\hline Barcelona & 1508800 & 1674.9 & 111.00 & 1200.0 & 79.53 \\
\hline
\end{tabular}

deaths, homeless population and the economic cost, among others. These models, in general, use empirical functions, developed starting from observed data during past earthquakes and are usually based on the knowledge of the occurrence probabilities of the physical damage state.

\subsubsection{Deaths and injured people estimation}

To evaluate the expected number of deaths and injured people, the casualty model given by Coburn and Spence (2002) has been applied. The occupancy rate of each building has been evaluated by assuming that reinforced concrete buildings contain more dwelling units and therefore more people due to their bigger size. Concerning the total floor area of masonry and reinforced concrete buildings, reasonable weights of 45 and $55 \%$ were assumed for masonry and concrete buildings, respectively. Thus, from the number of inhabitants for each census area, the number of inhabitants for each type of building has been estimated.

Two different scenarios have been assumed for the occupancy at time of the earthquake (Table 5) based on electric consumption in each district (Martí 2000). The first scenario (scenario 1) corresponds to the distribution of population during a work day in winter, with the maximum population in the city $(111 \%)$. The second one (scenario 2 ) corresponds to the lowest occupation (79.5\%) for a holiday in winter (day or night, as both have the same distribution).

Figure 18a and $\mathrm{b}$ depict the total casualties by census zones, evaluated for the probabilistic hazard scenario when it occurs in a working winter day (scenario 1) or in a day or night of a winter holiday (scenario 2), respectively. The difference between scenario 1 and scenario 2 when referring to casualties and injured people is about $1.5 \%$. Note that this difference can be observed in several census zones of the centre of the city, which have more population in a working day in winter than in a winter holiday.

The cause of most of the casualties and injured people is the collapse of reinforced concrete buildings. This is mainly due to the differences between the coefficients proposed by 

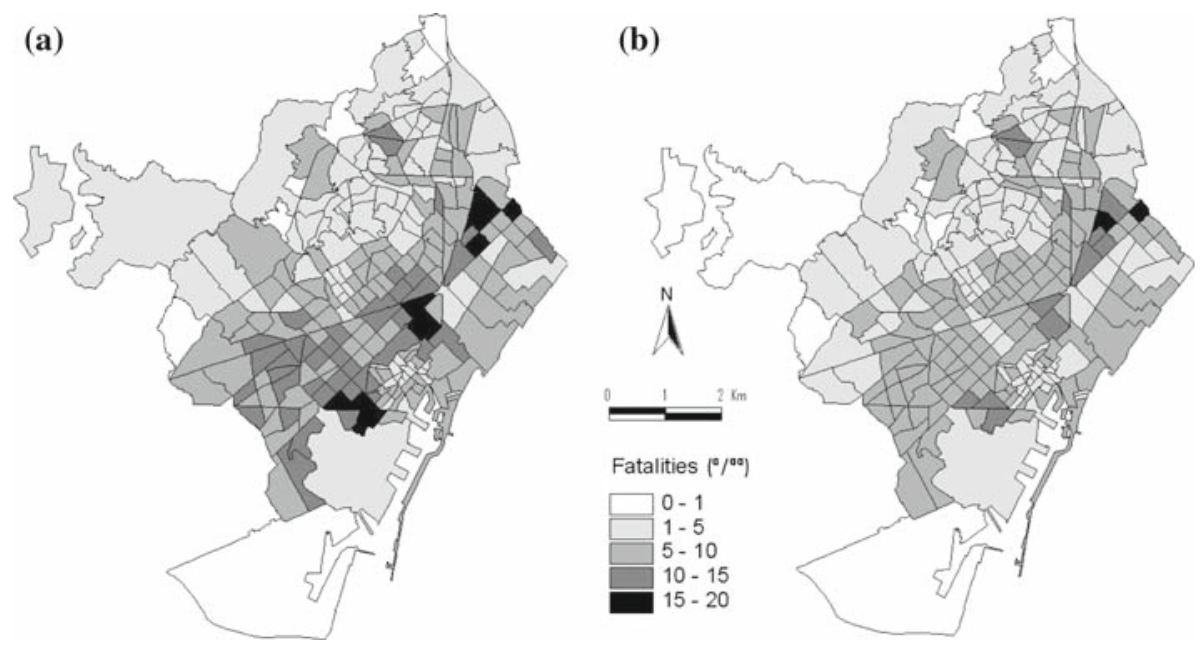

Fig. 18 Distribution of fatalities $(\%)$ for the probabilistic hazard case: (a) Scenario 1 working day in winter and (b) Scenario 2 day or night of a holiday winter

Coburn and Spence (2002), that in fact reveal the actual effect of the collapse of certain types of reinforced concrete buildings during past earthquakes (Coburn and Spence 2002). Expected casualties in an urban area are strongly correlated not only with the severity of the hazard scenario but also with the density of population and of the built area.

\subsubsection{Number of homeless estimation}

Other important information for disaster management is the number of persons that must be relocated due to the uninhabitable dwelling units. This value must be considered to designing the emergency plan of the city, in order to prepare temporary housing or adapt other facilities for accommodating homeless during a determined period of time.

The methodology to determine the number of uninhabitable residential units due to structural damage (UNUSD) is based on HAZUS 1999. This number is determined combining the number of uninhabitable residential units due to actual structural damage, with the number of damaged units that are perceived to be uninhabitable by their occupants. Based on comparisons with previous works (Perkins et al. 1996), the methodology considers the $100 \%$ of residential units located in buildings that are in the very heavy and destruction damage state and the $90 \%$ that are in substantial to heavy damaged structures to be uninhabitable. Therefore, total number of uninhabitable residential units due to structural damage is computed by the following relationship:

$$
\begin{aligned}
& \% \mathrm{MF}=0.9 \times \% \mathrm{H}_{\mathrm{MF}}+1.0 \times \% \mathrm{VH}_{\mathrm{MF}}+1.0 \times \% \mathrm{D}_{\mathrm{MF}} \\
& \mathrm{UNU}_{\mathrm{SD}}=\mathrm{U}_{\mathrm{MF}} \times \% \mathrm{MF}
\end{aligned}
$$

being $U_{\mathrm{MF}}$ the total number of multi-family residential units, $\% H_{\mathrm{MF}}, \% \mathrm{VH}_{\mathrm{MF}}$ and $\% D_{\mathrm{MF}}$ the damage state probability for substantial to heavy, very heavy and destruction structural damage state, respectively, in the multi-family residential occupancy class.

The total number of persons displaced from each building $i$ with a typology $t\left(P_{\mathrm{UNU}}\right)$, is obtained with the following relation, where $P_{h}$ is the number of persons who are assumed to live in each household of the building: 


$$
P_{\mathrm{UNU}}=P_{h} \cdot \mathrm{UNU}_{\mathrm{SD}}
$$

Figures 19a and 20a depict the total homeless people that can be expected from the considered deterministic and probabilistic earthquake hazard scenarios, respectively.

\subsection{Economic cost}

The economical losses are estimated as the present restoration cost of the damaged buildings. This value is determined by considering that reconstruction is made using reinforced concrete buildings and it does not include the land cost. However, the construction cost has increased considerably in the last years (about a $10 \%$ per year) and, taking in to account that the final cost depends on these values, two economic cost scenarios have been evaluated in this study. The first one provides the absolute economic cost $\left(S_{\text {Cost }}\right)$ in millions of Euros, given by the following equation:

$$
S_{\text {Cost }}=\sum_{k=2}^{5} \operatorname{CS}(k)=V_{C} \cdot \sum_{k=2}^{5} \sum_{j=1}^{\mathrm{Ne}}\left[\operatorname{Area}(j) \cdot P_{s}(k, j) \cdot \operatorname{RC}(k, j)\right]
$$

where $S_{\text {Cost }}$ is the sum of the $\operatorname{CS}(k)$ repair costs due to the damage state $k$ (damage state 1 none is not considered, because there is no any induced cost when there is no damage); $V_{C}$ is the cost per unit area for which a constant value of $V_{C}$ is assumed for all building typologies; Area is the building area; $\operatorname{PS}(k, j)$ is the probability for the building $j$ to be in the damage state $k$ and $\mathrm{RC}(k, j)$ is the repair value due to the damage state $k$ for the building $j ; \operatorname{RC}(k, j)$ is given as a percentage of the reposition cost per square meter. A reasonable value of $V_{C}$ for a residential building is $723 € / \mathrm{m}^{2}$ which corresponds to the Spanish construction market (Boletín Económico de la Construcción 2007). The second scenario gives the relative economic cost $\left(R_{\text {Cost }}\right)$, that is, the expected equivalent floor area destroyed by the earthquake. Thus, this economic cost can be defined from Eq. (8) as:

$$
R_{\text {Cost }}=\frac{S_{\text {Cost }}}{V_{C}}=\sum_{k=2}^{5} \sum_{j=1}^{\mathrm{Ne}}\left[\operatorname{Area}(j) \cdot P_{s}(k, j) \cdot \operatorname{RC}(k, j)\right]
$$

An additional economic loss due to the damage of residential building contents is about the $50 \%$ of the building restoration value (ATC-13 1985). This value is added to the structural cost, $S_{\text {Cost }}$, in order to obtain the total economic cost $T_{\text {Cost }}$.

As it can be seen in Eq. (9), there is a direct correlation between the economic cost amount and the built area. Figures $19 \mathrm{~b}$ and $20 \mathrm{~b}$ depict, respectively, $S_{\text {Cost }}$ in million of Euros for each census zone of the city, caused by the considered deterministic and probabilistic earthquake hazard scenarios.

\subsection{Debris generated}

The estimation of debris is performed empirically, based on observations of damage occurred in past earthquakes, for the damage states of the structural and non-structural elements (FEMA/NIBS 2002). Two types of debris are considered: (1) debris that falls in large pieces, e.g. steel members or reinforced concrete elements; (2) smaller debris, such like brick, wood, glass, building contents etc. Debris scenarios are obtained on the basis of the expected debris fraction $\operatorname{EDF}_{S}(d, t)$ of type $d$ will produce due to the structural damage state $k$ in a building typology $t$. This fraction is modelled by the following equation: 

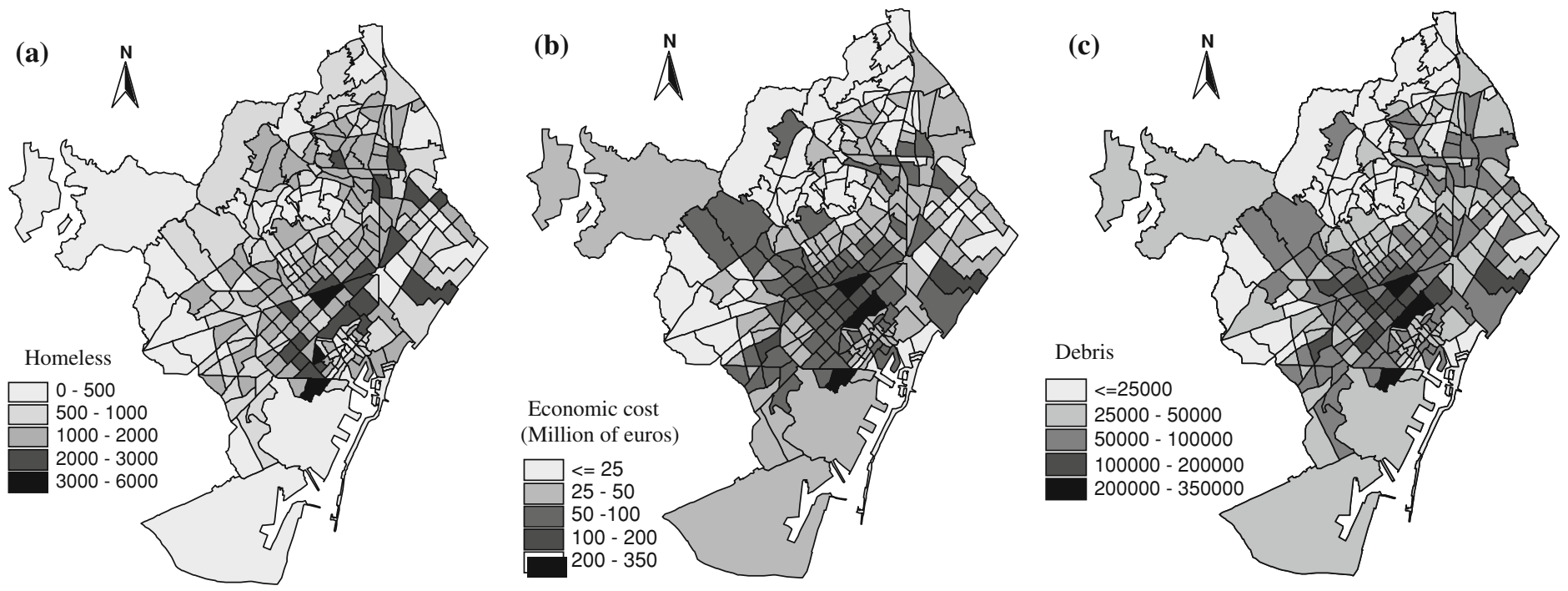
(a)

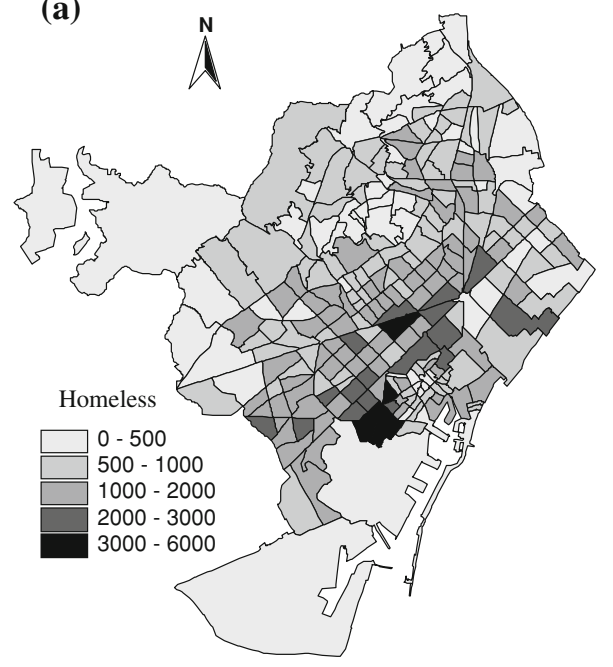

(b)

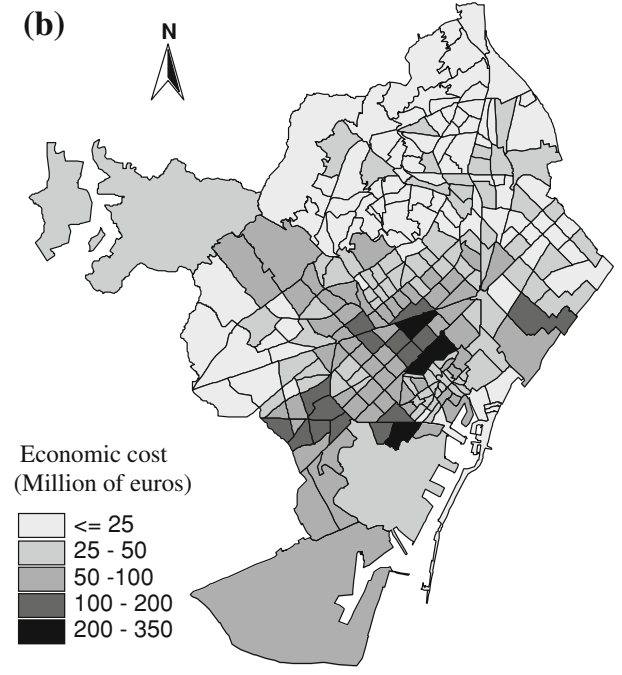

(c)

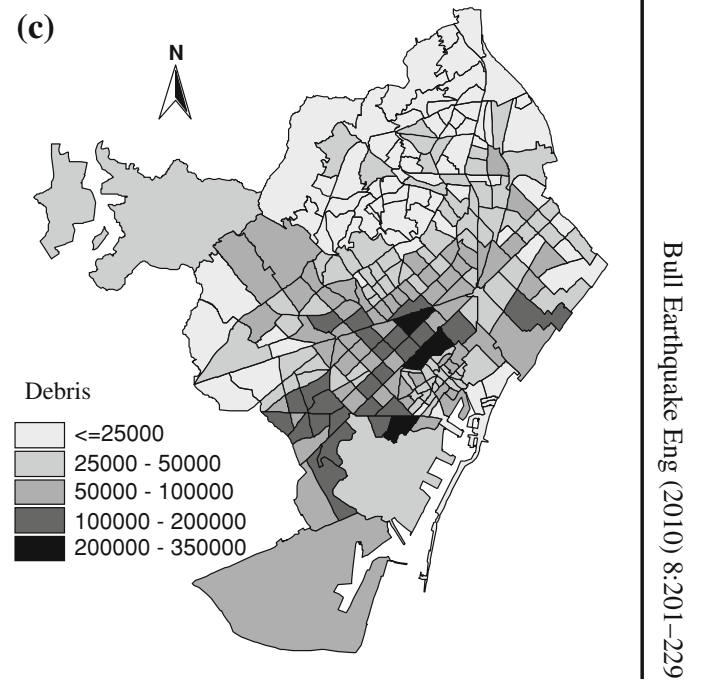




$$
\operatorname{EDF}_{S}(d, t)=\sum_{k=2}^{5} P_{S}(k, t) \cdot \operatorname{DF}_{S}(d, k, t)
$$

where $P_{S}(k, t)$ is the probability of a structural damage state $k$ for the building typology $t$ and $\mathrm{DF}_{S}(d, k, t)$ is the fraction of debris type $d$ for the building typology $t$ if the structural damage state $k$ occurs.

Finally the total debris weight, in tons, is obtained by summing, for each building of typology $t$ and for each debris type $d$, the built area multiplied by the $\operatorname{EDF}_{S}(d, t)$ debris fraction. Thus, in the assumed model, debris is produced by any non-null damage state and by means of the following equation:

$$
\operatorname{DF}_{S}(d, k, t)=W_{E}(d, t) \cdot \mathrm{GF}_{S}(d, j, t)
$$

where $W_{E}(d, t)$ are the structural element weights for materials of type $d$ and for the building typology $t . \mathrm{GF}_{S}(d, j, t)$ are the fractions of the structural element weight that is expected to result in debris due to the earthquake and they depend on the damage state $k$, the building typology $t$ and the debris type $d$. These coefficients have been adapted from HAZUS (1999) (Vacareanu et al. 2004).

Figures 19c and 20c show the debris scenario for the deterministic and probabilistic earthquake hazard scenarios, respectively. As it can be seen in Eq. (11), there is a direct correlation between the debris amount and the built area.

\subsection{Summary}

Results for seismic risk scenarios simulated for Barcelona are shown in this section. Important damages caused by the considered deterministic and probabilistic hazard scenarios are expected in Barcelona. The human loses would be between 5,000 and 9,000 fatalities (between 3.3 and 5.9 per thousand people), 4,000 and 6,500 injured people, and more than 250,000 homeless people. The economical loses estimated due to the structural damage cost rises at 10,000 million of Euros, and the total volume of debris would be higher than 10,000 tons.

Different seismic risk scenarios for the deterministic and probabilistic hazard are shown for census zones in Figs. 19 and 20, respectively. The scenarios of these figures provide average information easy to analyze and interpret, useful for preparedness, risk management and emergency planning.

\section{Discussion and conclusions}

The seismic risk assessment for current buildings and monuments of Barcelona has been performed by using the VIM established within the RISK-UE project. Spatial convolution between seismic hazard and vulnerability index, as well as damage probability matrices, allowed estimating the spatial distribution of the expected damage and losses associated to the hazard scenarios considered.

Due to the continuous changes related to the population, buildings, infrastructures and cost, that urban areas suffer, a GIS is the optimal tool for managing and updating all data necessary to evaluate seismic risk. In this sense, a significant contribution of the performed developments is the creation of a powerful and versatile tool implemented on a GIS. This application allows highlighting and discriminate the strong and weak points of the social and residential urban network, thus providing a better insight of the seismic risk state. 
In the case of Barcelona, the details and quality of the database, collected, improved and completed over the years for the current buildings of the city, allowed an accurate assessment of the vulnerability indices including the mean value and the modifiers related to the particular features of the individual buildings. It is worth noting that the modifiers of the vulnerability indices are calculated in a way different from the one proposed in the Risk-UE Project. In this way, the vulnerability and damage analysis has been made building by building, but was also calculated for different administrative areas. In particular, the census areas have been judged as the best evaluation scale for scenarios, because this level of representation allowed describing adequately the heterogeneity of the urban areas within the probabilistic frame of the study.

The seismic hazard for the city of Barcelona was evaluated in terms of intensity according to both the deterministic and probabilistic approaches, also including soil effects. The deterministic seismic hazard with soil effects in terms of intensity vary from VI to VIIVIII, while for the probabilistic scenario these intensities vary from VI-VII to VII. These intensities indicate that a certain degree of damage can be expected.

Based on these hazard scenarios, seismic risk scenarios have been developed, which show that in Barcelona, a city located in a low to moderate seismic hazard region, the high seismic vulnerability of the structures leads to a considerable expected risk. It is worth noting that the original results described in this article, together with the complete and detailed technical information concerning the expected damage, loss to property and casualties, have been delivered to the civil protection services of the municipality who are using them for updating the emergency plans of the city. In order to study the effect of the influence of the population flow to and from the city, two different scenarios of casualties have been developed, the first due to a seismic event occurred during a winter working day and the second one during a winter night holiday. The seismic damage evaluation for the most important cultural heritage buildings of the city using the VIM revealed that churches are the most vulnerable monuments. Most of the vulnerability indices adopted for the buildings and monuments of Barcelona may be directly used in obtaining risk scenarios for other cities of Spain, in particular for those of the Mediterranean region.

The maximum mean damage state expected for Barcelona's residential buildings and monuments correspond to a level of slight to medium for the deterministic scenario. This method has proven to be a simple statistical tool for evaluating the vulnerability of residential buildings and monuments when limited information is available, because the results it provides are comparable with those obtained by using more sophisticated mechanical methods.

Validation of results is crucial for any seismic risk assessment method, but this is not a trivial issue for earthquake scenarios because of the great uncertainties involved. The best validation test would be the real occurrence of the simulated earthquake scenario; agreement between simulations and observed damage would validate both the method and the quality of the data used. Some alternative validation procedures can be based on data from similar earthquake scenarios, numerical simulations performed with other methods or expert judgement. In this case, the VIM method is based on the EMS-98 intensity scale and data are highly accurate; vulnerability curves are well calibrated by using this scale and the assessment of the vulnerability indices has been made by using accurate information existing for each building in the database, showing an excellent agreement with the historical evolution and the current state of the city. Moreover, the results based on the VIM method show damage and losses distributions similar to those obtained for the city using the capacity spectrum based method (CSBM) as proposed in the framework of the Risk-UE project. For these reasons, the risk scenarios developed in this article are considered to be reliable. 
Acknowledgments This work has been partially sponsored by the Spanish Ministry of Education and Science and with FEDER funds (projects: CGL2004-22325-E, CGL-2005-04541-C03-02/BTE, HABITAT 2030-PSS-380000-2005-14 and SEDUREC-CSD2006-00060) and by the European Commission (RISK-UE Project -EVK4-CT-2000-00014).

\section{References}

Anagnos T, Rojahn C, Kiremidjian A (1995) NCEER-ATC joint study on fragility of buildings, Report NCEER95-0003. National Center for Earthquake Engineering Research, Buffalo

ATC-13 (1985) Earthquake damage evaluation data for California, ATC-13. Applied Technology Council, Redwook City

Barbat AH, Moya FY, Canas JA (1996) Damage scenarios simulation for seismic risk assessment in urban zones. Earthq Spectra 12(3):371-394

Barbat AH, Mena U, Yepez F (1998) Evaluación probabilista del riesgo sísmico en zonas urbanas. Revista Internacional de Métodos Numéricos para Cálculo y Diseño en Ingeniería 14:247-268

Barbat AH, Pujades LG, Lantada N (2006) Performance of buildings under earthquake in Barcelona, Spain. Comput Aided Civ Infrastruct Eng 21: 573-593

Barbat AH, Lagomarsino S, Pujades LG (2006b) Vulnerability assessment of dwelling buildings. In: Sousa C, Roca A, Goula X (eds) Assessing an managing earthquake risk. Springer, Dordrecht, pp 115-134

Barbat AH, Pujades LG, Lantada N (2008) Seismic damage evaluation in urban areas using the capacity spectrum method: application to Barcelona. Soil Dyn Earthq Eng 28(10-11):851-865 (special issue Urban earthquake hazard and damage assessment)

Barbat AH, Carreño ML, Pujades LG, Lantada N, Cardona OD, Marulanda MC (2009) Seismic vulnerability and risk evaluation methods for urban areas. A review with application to a pilot area. Struct Infrastruct Eng. doi:10.1080/15732470802663763

Bard PY (1997) Local effects on strong motion ground motion: basic physical phenomena and estimation methods for microzoning studies, In: SERINA: seismic risk and integrated seismological, geotechnical and structural approaches. ITSAK, European Commission, Directorate General for Science and Development

Benedetti D, Petrini V (1984) Sulla vulnerabilitá sismica di edifici in muratura: proposte di un metodo di valutazione. L'industria delle Construzioni 149:66-78

Bernardini A (2000) The vulnerability of buildings_-evaluation on a national scale of the seismic vulnerability of ordinary building. CNR-GNDT, Rome

Boletín Económico de la Construcción (2007) Revista trimestral de precios del ramo de la construcción. Año LXVIII, trimestre 4. No. 272

Carreño ML, Cardona OD, Barbat AH (2007) Urban seismic risk evaluation: a holistic approach. Nat Hazards 40:137-142

Carreño ML, Cardona OD, Barbat AH (2007) Disaster risk management performance index. Nat Hazards 41:1-20

Castellò D, Mañà F (2003) Study of the seismic vulnerability of the city of Barcelona within the framework of the Risk-UE European project. RISK-UE project: an advanced approach to earthquake risk scenarios with applications to different European towns. Contract No.EVK4-CT-2000-00014, Barcelona

Cid J, Susagna T, Goula X, Chavarria L, Figueras S, Fleta J, Casas A, Roca A (2001) Seismic zonation of Barcelona based on numerical simulation of site effects. Pure Appl Geophys 158:1-19

Coburn A, Spence R (2002) Earthquake protection, 2nd edn. Wiley, Chichester

Cornell CA (1968) Engineering seismic hazard analysis. Bull Seismol Soc Am 59(5):1583-1606

Departament d'Estadistica (2007) La població de Barcelona, 2006. Ajuntament de Barcelona, Barcelona (in catalan)

Egozcue JJ, Barbat A, Canas JA, Miquel J, Banda E (1991) A method to estimate intensity occurrence probabilities in low seismic activity regions. Earthq Eng Struct Dyn 20:43-60

Faccioli E (2006) Seismic hazard assessment for derivation of earthquake scenarios in Risk-UE. Bull Earthq Eng 4:341-364

FEMA/NIBS (2002) Earthquake loss estimation methodology, HAZUS-99 service release 2 (SR2) technical 533 manual. National Institute of Building Sciences for the Federal Emergency Management Agency, 534, Washington, DC

Fleta J, Escuer J, Goula X, Olivera C, Combes Ph, Grellet B, Granier Th (1996) Zonación tectónica, primer estadio de la zonación sismotectónica del NE de la Península Ibérica (Cataluña). Geogaceta 20:853-856 
Giovinazzi S, Lagomarsino S (2002) Wp04: guidelines for the implementation of the level I methodology for the vulnerability assessment of current buildings. RISK-UE project: an advanced approach to earthquake risk scenarios with applications to different European towns. Contract No.EVK4-CT-2000-00014, Genoa

GNDT: Gruppo Nazionale per la Difesa dai Terremoti (1994) Scheda di esposizione e vulnerabilità e di rilevamento danni di primo livello e secondo livello (muratura e cemento armato), Roma

Goula X, Godefroy P (1985) Évaluation de l'alea simique regional. Zonage à petite échelle. Génie Parasismique, pp 207-221

Grellet B, Combes Ph, Garnier Th, Phillip H (1993) Sismotectonique de la France Métropolitane. Mémories de la Sociéte Géologique de France, No 164, vol I, 76 pp

Grünthal G (1998) European macroseismic scale 1998. Centre Européen de Géodynamique et de Séismologie, Luxemburg

Gutenberg B, Richter CF (1954) Seismicity of the earth and associated phenomena. Princeton University Pres, New Jersey

HAZUS (1999) Earthquake loss estimation methodology technical manual, prepared by the National Institute of Building Sciences for Federal Emergency Management Agency (FEMA), Washington, DC

INFOCCA (2002) Informació del Centre de Cartografia Automàtica (INFOCCA). Institut Municipal d'Informática, Ajuntament de Barcelona (in catalan)

Irizarry J (2004) An advanced approach to seismic risk assessment. Application to the cultural heritage and the urban system of Barcelona. Ph.D. Thesis, Universitat Politècnica de Catalunya, Barcelona

Irizarry J, Goula X, Susagna T, Roca A, Mañá F (2004) Earthquake risk scenarios for monuments in Barcelona, Spain. In: Proceedings of the 13th world conference on earthquake engineering, Vancouver

Kappos A, Pitilakis K, Stylianidis K, Morfidis K (1995) Cost-benefit analysis for the seismic rehabilitation of buildings in Thessaloniki, based on a hybrid method of vulnerability assessment. In: Proceedings of the 5th international conference on seismic zonation, Nice,vol 1, pp 406-413

Kallberg KT, Cornell CA (1969) Seismic risk in Southern California. Research Report MIT, Department of Civil engineering, Boston

Lagomarsino S (2006) On the vulnerability assessment of monumental buildings. Bull Earthq Eng 4:445-463

Lagomarsino S, Giovinazzi S (2006) Macroseismic and mechanical models for the vulnerability and damage assessment of current buildings. Bull Earthq Eng 4:415-443

Lagomarsino S, Giovinazzi S, Podestà S, Resemini S (2003) Wp5: vulnerability of historical and monumental buildings handbook. RISK-UE: an advanced approach to earthquake risk scenarios with applications to different European towns. Contract No. EVK4-CT-2000-00014

Lagomarsino S, Podestà S, Resemini S (2004) Observational and mechanical models for the vulnerability assessment of monumental buildings. In: Proceedings of the 13th world conference earthquake engineering, Vancouver

Lantada N (2007) Evaluación del riesgo sísmico mediante métodos avanzados y técnicas GIS. Aplicación a la ciudad de Barcelona. Doctoral Thesis. Technical University of Catalonia, Barcelona Available via DIALOG. http://www.tdx.cat/TDX-0401109-133809. Accessed 30 Jan 2009

Lantada N, Pujades LG, Barbat AH (2008) Vulnerability index and capacity spectrum based methods for urban seismic risk evaluation. A comparison. Nat Hazards. doi:10.1007/s11069-007-9212-4

Lungu D, Aldea A, Arion A, Vacareanu R, Petrescu F, Cornea T (2001) WP1 report: European distinctive features, inventory database and typology. RISK-UE project: an advanced approach to earthquake risk scenarios with applications to different European towns. Contract No. EVK4-CT-2000-00014

Martí JO (2000) Anàlisi de risc sísmic en la ciutat de Barcelona. Aspectes relacionats amb l'evolució espaitemporal del risc, Universitat Politècnica de Catalunya (in catalan)

Milutinoviç ZV, Trendafiloski GS (2003) WP04: vulnerability of current buildings handbook. RISK-UE project: an advanced approach to earthquake risk scenarios with applications to different European towns. Contract No. EVK4-CT-2000-00014, Institute of Earthquake Engineering and Engineering Seismology (IZIIS), Skopje

McGuire R (1976) EQRISK: evaluation of earthquake risk to site. Fortran computer program for seismic risk analysis. US Geological Survey Open File Report 76-67

Mouroux P, Bertrand M, Bour M, Brun BL, Depinois S, Masure P, Risk-UE Team (2004) The European Risk-UE project: an advanced approach to earthquake risk scenarios. In: Proceedings of the 13th world conference earthquake engineering, Vancouver (CD-ROM, Paper No. 3329)

MSK-81 (1981) Seismic intensity scale in report on the ad-hoc panel meeting of experts on up-dating of the MSK-64 seismic intensity scale. Jena, 1981. Gerlands Beitr Geophys, Leipzig

NCSE-02 (2002) Normativa de Construcción Sismorresistente Española, Comisión Permanente de Normas Sismorresistentes, Real Decreto 997/2002. Boletín Oficial del Estado No. 244 del 11 de octubre de 2002 
NCSE-94 (1994) Norma de Construcción Sismorresistente Española, Parte General y de Edificación, Comisión Permanente de Normas Sismorresistentes, Real Decreto 2543/1994, Boletín Oficial del Estado No 33 del 29 de Diciembre de 1994: 3936-3980

Olivera C, Riera A, Lambert J, Banda E, Alexandre P (1994) Els terratrèmols de l'any 1373 al Pirineu: efectes a Espanya i França. Servei Geològic de Catalunya. Generalitat de Catalunya, Monografies, No. 3

Paricio A (2001) Secrets d'un sistema constructiu: l'Eixample. Edicions UPC, Barcelona

Perkins JB, Harrald J, Jeong D, Chuaqui B (1996) Shaken awake estimates of uninhabitable dwelling units and peak shelter populations in future earthquakes affecting the San Francisco Bay region. Association of Bay Area Governments, Oakland

PGS-1 (1968) Norma sismorresistente PGS-1(1968), parte A, Comisión Interministerial de la Presidencia del Gobierno, Decreto 106/1968, del 16 de enero de 1969

Secanell R (1999) Avaluació de la perillositat sísmica a Catalunya: anàlisi de sensibilitat per a diferents models d/ocurrència i paràmetres sísmics, Ph.D. Thesis, University of Barcelona

Secanell R, Goula X, Susagna T, Fleta J, Roca A (2004) Seismic hazard zonation of Catalonia, Spain, integrating uncertainties. J Seismol 8:24-40

Singhal A, Kiremidjian AS (1996) Method for probabilistic evaluation of seismic structural damage. J Struct Eng ASCE 122(12):1459-1467

Sponheuer W (1960) Methoden zur Herdtirefenbestimmung in der Makroseismic. Freiberger Forschungshefte, $\mathrm{C} 88$

Susagna T, Goula X (1998) Atlas Sísmic de Catalunya, vol 1. Institut Cartogràfic de Catalunya

Udwin D (1981) Introductory spatial analysis. Ed. Methuen, London

Vacareanu R, Lungu, D, Aldea A, Arion C (2004) WP07: report seismic risk scenarios handbook. Risk-UE Project, Bucarest

Whitman RW (1973) Damage probability matrices for prototype buildings. Massachusetts Institute of Technology, Department of Civil Engineering Research, Report R73-57, Cambridge 